\title{
Global Forces and European Competition
}

The elites of the Iberian kingdoms had been able to confront the problems of reproduction that faced them in the fifteenth century. As has been said, the empire was both the problem and solution, particularly for Castilian and Portuguese societies. But other areas of Europe confronted similar challenges, the main difference being the way they were approached and resolved. The results would be varied and decisive for Europe, as they would shape the different political economies of the continent. In all these cases, and sometimes in an indirect way, these outcomes were also conditioned by the process of globalization itself and by transnational factors, above all the wars into which the global Iberian empires would be drawn and the flows and currents of wealth and silver that they produced. The indirect result would be a first, if somewhat uncertain, step towards a model of greater polarization of growth which gravitated towards the north of Europe and linked it to a cycle of the longue durée in the relationship between resources and population. ${ }^{1}$ This

${ }^{1}$ See Braudel (1976, vol. II, p. 791), among others. According to Braudel, the greater level of tension between resources and population in the south ended up facilitating the introduction of wheat by the Dutch and English in the Mediterranean, which they would then supplement with a growing trade in industrial products from the North. His thesis was later criticized by J. Israel, who drew attention to the need to avoid speaking of the north of Europe but rather about 'a tiny fringe, the extreme north western corner of the continent' (1989, pp. 5-11, 1990, pp. 133-161).

(C) The Author(s) 2019

B. Yun-Casalilla, Iberian World Empires and the Globalization of Europe 1415-1668, Palgrave Studies in Comparative Global History, https://doi.org/10.1007/978-981-13-0833-8_6 
chapter aims at analysing how, in a context of increasing globalizationfor the epoch's standards-silver flows associated with warfare, market integration within Europe, and political-religious developments affected the different institutional frameworks and consequently the economic competition among distinct Western European regions.

\section{Religion As a Factor: Western European Patterns OF DEVELOPMENT}

Economic historians are increasingly interested in the impact and influence of religion upon institutions and material development. They have usually contented themselves with examining how beliefs had economic effects, thinking along lines first suggested by Max Weber (Grier 1997). However, it is worthwhile underlining that its effects should also be considered from the viewpoint of the functioning of the institutions in question. As we have seen (Chap. 5), the influence of religiosity through the specific management criteria that it introduced into ecclesiastical institutions was notable. Moreover, its impact on political economies that so much depended upon social and political stability also should be considered. To this end, it is important to remember that sixteenth-century religion meant something more than individual and private sentiment with limited effects or impact upon public life. Political theory as much as political practices had sacred roots and origins as, therefore, did the functioning of the institutions. The former was based on the vision of the body politic as a community of religious ideas. From this concept sprang the idea of cuius regio eius religio. The spread of different forms of interpretation of devotion implied a rupture of the political and social body. This was a break that could be manifested at the level of the body politic and society as a whole, at the level of the state as an articulation of different powers and at the very level of coexistence and local politics and that above all affected the chances of reproduction of the elites' conflictive pacts.

A brief examination of events in other countries and the means of consolidation - or rupture - of institutional systems may cast light on this fact and on fundamental differences in the history of Europe.

Economic growth continued in France throughout the sixteenth century. If agrarian expansion was extensive, the spread of métayage and farms rented by well-off peasants allowed for improvements and investment in working tools and organizational innovations that improved the total factor productivity (Hoffman 1996, pp. 98-107). International commerce 
and the political solidity of the cities favoured the development of a urban network, with crucial nodes in the coastal areas but a strong penetration of the interior (Benedict 1989). This fact enhanced the development of rural markets and the commercialization of peasant production.

But this growth did not bring about a profound change in the political economy that governed the relations between the cities, the aristocracy, the Church, and the king. Until well into the century, the French Crown was unable to perfect its tax system and so create a fiscal state that involved the entire kingdom in tax collection; only some steps were taken towards the centralization and co-ordination of this system (Wolfe 1972, p. 104). The composite character of the monarchy and its system of checks and balances, similar to that of Castile, was maintained (Chap. 1). The cities not only retained their autonomy but even increased it to the extent that they became the credit bases of the Crown and assumed a sizeable portion of its debts (Chevalier 1987, pp. 150-151). Both the états provinciales, provincial representative assemblies, and the negotiating power of the urban oligarchies remained intact. Moreover, the États généraux", in which the kingdom used to meet, also retained scope for manoeuvre. As in the Iberian territories, the aristocratic families faced considerable difficulties in reproducing the social control of their lineages. We know today that the vigour of this group did not fall in general. Royal service allowed its members access to the wealth extracted by the fiscal system, and its incomes could be adapted to the depreciation brought about by the price revolution (Russell Major 1981; Salmon 1975, pp. 81-84). The military contributions of the 'second nobility' created channels for social advancement that contributed to overcome the internal tensions of the patriciate and the lower ranks of the aristocratic lineages (Bourquin 1994, pp. 24-58). The purchase of fiefs and seigniorial estates from both private individuals and the Crown allowed magistrates and businessmen to satisfy the need for expansion felt by the urban oligarchies (Salmon 1975, p. 42). At the same time, this trend increased the monarch's capacity for arbitration, set down in the growing influence and number of the 'men of the king' in the provinces (Jouanna 1989, pp. 80-90) and in their growing role as administrators of the condition of the noble. As in the Iberian kingdoms, the Church served as the machinery for absorption of this dynamic of social promotion. This came at the time that its jurisdictional autonomy and powers in relation to the king were retained to the extent that French royal absolutism has been seen as a relatively well-balanced political system (Beik 1985). 
Towards 1550 agriculture entered a phase characterized by falling yields while the fragmentation of many farms lowered overall land productivity. Fiscal pressure was transferred onto the countryside, and urban salaries fell (Neveux et al. 1975, pp. 151-155). War with the Habsburgs led to an unprecedented increase in fiscal pressure and a reduction of the percentage of the royal taxes that remained in the hands of the cities charged with their collection, thus creating even more conflicts. Crown debts, which impacted cities such as Lyon and Paris, led to the bankruptcy of 1557-1558 (Chevalier 1987, pp. 150-151; Wolfe 1972, pp. 104-118). While unthinkable in Castile, the displacement of part of the fiscal burden towards the Church forced it to sell off ecclesiastical properties (Wolfe 1972, pp. 118-123). According to some calculations, during the sixteenth century, some $50 \%$ of ecclesiastical possessions were sold off. Nothing similar happened in Castile, although the seigniorial estates of some clergy were alienated. Moreover, the development of the French royal fiscal system threatened to break relations with the aristocracy (Chaunu 1977, pp. 166-167). This came at a moment at which families such as $\mathrm{La}$ Trémouille and others had problems achieving the extension of their lineages. The tension among noble households, structural to the system, increased. ${ }^{2}$

For these reasons the differences in regard to the Spanish Habsburg dominions were very clear. In geographical terms France was a geopolitically unified monarchy boasting a high density of population. On the other hand, it did not possess an empire with which to offer an outlet for the dominant coalition's needs for consolidation and extension. Nor could it count upon a stream of American silver to allow it to form an efficient system for assuming and consolidating debts (see Chap. 4). This having been said, the breakdown of the medieval model would be brought about by an external factor that was totally alien to the previous institutional framework and largely absent in Castile: religious division. If the Catholic Church had exercised less influence upon the French monarchs' international politics, the religious rupture would be a key factor in the history of the country.

The spread of Calvinism among society in general and the nobility in particular (leading to the rapid 'contamination' of its clients), and the subtlety of its doctrine on the subject of resistance to the king, fell upon a

\footnotetext{
${ }^{2}$ See the cases of the Guise, Montmorency, and the Bourbons (Knecht 1996, pp. 15-18).
} 
receptive terrain marked by the growing discontent over the Crown's fiscal policies (Jouanna 1989; Wood 1980, p. 169). This was happening at the same time that the 'aristocratic structure of power was converting a civil war into a drama of a religious nature' (Chevalier 1994, p. 391). Coming on top of the radicalization of court factions, religious confrontation would lead France into one of the most tragic periods of its history.

The subsequent conflicts brought into the open problems in the stability of the social system and, in particular, of the noble economies within it. The 'state of finances' that had served as a basis for the continuity of the social system was falling apart, and taxes were replaced on both sides by pillaging and sacking (Chaunu 1977, pp. 170-175). And with the collapse of the old arrangements, the social equilibrium achieved in the previous century also disintegrated. The nobility sought to overcome its needs by seizing communal lands and extending its dominions, as it had done during the Middle Ages. Many cities claimed greater degrees of autonomy or, as was the case where the Protestants formed the majority, boosted and extended their self-government (Knecht 1996, pp. 53-54). All of this was combined with peasant uprisings against taxes, resistance to payment of the tithe, and even the radicalization of popular groups in the cities.

As had been the case for the war of the Comunidades of Castile and the Germanias of Valencia, the wars of religion brought to the light grave problems within the existing social system. But, in the same way as in the Iberian kingdoms, the wars convinced the nobility, magistrates, the Church, the Catholics, Huguenots, and all the well-off sectors of French society that the only way out was order and political stability. And this order could only be achieved with a strong and absolute monarch ('an official of God on the Earth'). This figure was finally embodied in Henry of Bourbon, King of Navarre, proclaimed King of France after his renunciation of Protestantism in 1594. From this moment, the political rhetoric changed in respect to the theories - tyrannicide included - of the sixteenth century (Holt 1995, pp. 213-216). The treasury reforms of Sully strengthened royal power and gave it new resources of patronage that allowed it both to attract elites and to oversee the restructuring of the dominant coalition (Salmon 1975, pp. 276-308). If religious conflict did not entirely disappear, the confrontation over different creeds was overcome for the moment. This supposed a decisive step forward for order and the reproduction of the social and political systems. The economic consequences of this situation would be crucial. 
In England the institutional system that emerged from the medieval crisis had less scope to redistribute rents and revenues among the elites (Chap. 1). A large part of the Crown's income came from its own royal patrimony or from import and export duties. ${ }^{3}$ The social dominium of aristocratic lineages was maintained by extending their possessions and the establishment of great estates (Brenner 1993). Given the limits of the fiscal system, the urban oligarchies enjoyed fewer chances to exploit their autonomy or to mediate the collection of taxes. Shortly, they found themselves committed to the consolidation of their agrarian properties or to commerce as a means of expansion. Although this was a zone of very low levels of urbanization at the start of the century, the town oligarchies achieved very noticeable levels of economic and demographic growth based upon significant improvements in commerce, urbanization, and extensive agriculture that brought about an increase in productivity. ${ }^{4}$ Probably this growth is most clearly reflected in the accelerating rhythms of urbanization. Moreover, these rates may be underrepresenting economic progress, if we take into account the extension of the putting out system which led to a high level of industrial productivity without a proportional development of the major cities.

The institutional system suffered from crucial problems. As in Castile, the aristocracy had to make assiduous use of credit (Stone 1979, p. 509). The growth of the regular income of the Crown was being steadily mitigated by the rise in prices, while royal expenditure shot through the roof at each and every moment of tension in foreign affairs. The Crown's capacity to increase its core revenue in England was lower than in Castile (see Graph 4.1). The origin of this limitation lay in part in the difficulties and costs involved in the management of the Crown lands (Russell 1988, pp. 31-33) and the slow increase in import and export duties, as well as in the stagnation in real terms of tax receipts (O'Brien and Hunt 1993). Henry VIII governed thanks to the support of the gentry in Parliament and the use of statutes that strengthened his absolute authority (Loades 1994, p. 411); but a system of this kind also increased the demands of patronage, manifested, for example, in a certain level of permissiveness in the cession of Crown lands to the nobility (Russell 1988, p. 32). As in other areas of Europe, the power system was already driven by grave tensions in the first half of the century.

\footnotetext{
${ }^{3}$ See figures in Hough and Grier $(2015$, p. 144) that come from Cunningham (2007).

${ }^{4}$ For this, see De Vries (1994, p. 13), De Vries (1984, p. 56), O’Brien (1996, p. 216), Overton (1996, p. 82), and Snooks (1994, p. 41).
} 
The fortuitous factor that would most affect the reproduction of the social and institutional model would be Henry VIII's break with Rome and the creation of the Church of England. Despite the personal origins of this decision, it must be seen in the general European context, marked by tensions between monarchy and pontificate, as well as the Crown's need for increasing resources. Perhaps for these reasons, the effects upon the institutional system were crucial. The Reformation allowed the seizure and sale by the Crown of extensive ecclesiastical possessions during the reign of Henry VIII (monastery lands constituted one-fifth of the total land under cultivation) and then under Elizabeth I (the estates of the bishops). ${ }^{5}$ This decision broke decisively with the model as it developed in Castile, which was based upon the amplification of ecclesiastical properties, and would have enormous impact upon the assignation of productive factors and the political economy (Chaps. 4 and 5).

The English Reformation also turned out to be crucial for economic and social development. It fed the expansion of the noble and gentry estates, the principal purchasers of the church lands. It permitted the promotion and reproduction of both social groups upon the basis of the establishment of extensive properties and, moreover, strengthened their affinities with the Crown as a result of the rupture with Rome, leading to a corresponding tightening of Crown control over this new nobility of proprietors (Hill 1969, p. 35; Stone 1979).

During the reign of Elizabeth (1558-1603), the rise of the gentry, the purchase of honours, and the problems of the old aristocratic lineages became more noticeable (Stone 1979, pp. 250-257). Unable to exert a firm grip over their possessions as enjoyed by their counterparts in Castile (achieved through the semi-public institution of the mayorazgos, combined with the peculiar system of mortgages taken out on possessions tied to them), denied access to a highly evolved fiscal apparatus such as that of Castile and even France, and without an empire and an international composite monarchy, such as the Spanish one that would allow the nobility to enjoy both massive incomes from the state and political space in which to expand, the English aristocrats' indebtedness would lead them to sell their possessions, a measure that successively renewed and changed their social group.

\footnotetext{
${ }^{5}$ Hough and Grier (2015, pp. 144-145), based mainly on Elton (1953, pp. 247-249) and Black (1959, pp. 14-34).
} 
The social role of the high nobility began to change from the last years of the sixteenth century. The need to exploit its estates more intensively and efficiently and to invest in different sectors of the economy reduced the importance of the economy of legitimation (Chaps. 1 and 4) of many families (Stone 1979). The military character of the class disappeared almost entirely to the extent that war now depended upon the navy, an institution relatively highly controlled by the monarch and therefore crucial for state building (Glete 2000, pp. 67 and 147). If the cities maintained functions of social legitimation similar to those of Castile or France, their involvement in the fiscal system and in the distribution of resources was much less pronounced than in these countries, a factor that would affect their role in the institutional system (Chap. 4).

In some regards the political economy of England at the end of the century was similar to that of Castile or France. The judicial system had certainly developed, but corporative institutions controlled by merchants, such as the Merchant Adventurer Companies (Brenner 1993), the cities, or the old nobility, created forms of self-enforcement that limited the monarch's capacity for arbitration and juridical coercion. But in this regard, the evolution was very different, and, more important, the elites' coalition had been broken, and this led the country along a road of no return (in distinction to France), thus making it an exceptional case in the history of Europe. Despite the court corruption and patronage denounced during the reigns of James I (1603-1625) and Charles I (1625-1649), the merchant classes and the high nobility continued to enjoy far fewer chances to consolidate and extend its power though the institutions, access to political incomes or patronage, and corruption than their counterparts in Castile and Portugal-with all their empires - or even France. For the English nobles, it was necessary to return to overseas commerce while exerting pressure upon Parliament for a foreign policy that ranked commerce above dynastic or noble interests and that would override the concerns of those corporations that were constituted as the Merchant Adventurers (Brenner 1993). These overseas merchants retained a number of powers and even enjoyed a noticeable degree of access to violence that would afford them a certain advantage in the use of methods of enforcement. But they would slowly convert themselves into great agricultural proprietors and mine-owners, while their jurisdictional powers were steadily reduced. For this reason, they found it increasingly important to introduce productive improvements that would increase the efficiency of their mines and farming estates, even if this entailed rising social tensions 
with their subjects that came to cost them their image as paternalists and defenders of the traditional order (Stone 1979). Nothing like a double economy as described or as could be found in Castile was discernible in the isles, at least not with similar dimensions (Yun 2002a). In contrast to the mayorazgos, the English strict settlements were not adorned with any institutional mechanism that prevented the dissolution of patrimonies, and, consequently, they were not effective in this sense (Habakkuk 1994). And nothing like a network of ecclesiastical institutions governed by criteria of pure social profitability and legitimation existed in dimensions comparable to those of Castile, France, or even Portugal. Although what is referred to in this study as the economy of legitimation appears to be highly developed to English historians, who use the term 'economy of welfare', it is almost certain that English provision and spending would not resist comparison with the figures from the continent (Archer 1991; Slack 2015, p. 64).

Yet if this process had produced only partial effects, the outcome of this rupture was evident before the changes usually dated to 1688 (North and Weingast 1989): it would be manifested in social instability and political tensions leading to the decisive breakdown of $1640 .{ }^{6}$

The development of the Low Countries during the Middle Ages had been based upon commercial and industrial growth. The nobility, if present and significant in many areas, had much less economic, social, andabove all-jurisdictional power than in Castile or France (Van Nierop 1984, pp. 38-39; Israel 1995). Political fragmentation was reflected in considerable fiscal segmentation, and this compelled Charles V to enter into a seemingly endless round of separate negotiations (Chap. 4). Like his grandfather, the Emperor Maximilian, Charles V did not attempt to introduce radical changes in political and institutional organizations (Koenigsberger 1971, pp. 125-143). Despite reforming the treasury and arrangements governing the central finances, he did not carry out changes that would have resolved tensions between the Crown and the estates or between the provinces. The fiscal needs of the kingdom were covered largely by credit agreements set upon Crown possessions. But, given their

\footnotetext{
${ }^{6}$ These arguments, first presented in a more intuitive way in Yun (2004), have been clarified and given depth by Hough and Grier (2015, pp. 137-149) from whom some of these ideas are borrowed. Some nuance should be introduced to the vision presented by North and Weingast (1989) where the change is dated to the transformations of 1640 and more specifically 1688 . Both visions are not mutually exclusive.
} 
decline and indebtedness - in the 1520s they barely brought in 16\% of overall income-it was impossible not to recur to voted subsidies from the estates and the development of the fiscal state. ${ }^{7}$ The outcome would be a marked dependence upon the parliamentary assemblies that controlled not only the vote on the services but also the collection of these incomes and the emission of renten, debt bonds that allowed money to be advanced to the Crown (Tracy 1985). As in other kingdoms, a system of this sort brought with it the risk of corruption and bribery that would reduce the final amount collected (Koenigsberger 1971, pp. 166-175).

Set in the most dynamic area of European poly-nuclear economic growth, and with an ever-more intensive agriculture, the economic expansion of this region was very impressive, as can be seen from its high rates of urbanization (Van der Wee and Blomme 1994; Klep 1988; Israel 1995, pp. 113-116). This model, however, created important tendencies towards social instability. The scope for development of an aristocracy that might exercise coercion in alliance with the Crown, and so guarantee social order, was minimal. Moreover this group, which also had considerable debts, quickly overcame them through improvements in its productive system (Van Nierop 1984). In reality, this was the only viable option in light of the limits of the system for the redistribution of incomes, given the overall curbs on a system fully controlled by the states and the extent to which Castilian families were displacing their Flemish and Dutch peers in the government of the monarchy (Koenigsberger 1971). And something similar might be said of the businessmen and artisans whose social reproduction depended upon their involvement in the international market rather than upon political or fiscal incomes that could be obtained at the local level. If the cities maintained and even strengthened their fiscal autonomy, the urban economy rested upon other pillars that rendered it less dependent upon this fact.

Taxes upon commerce and consumption, the Habsburg wars-above all those with France - and fiscal demands had a destabilizing effect (Tracy 1985, pp. 75-107). The preoccupation in Madrid with religious 'contamination' led to the establishment of the Inquisition, a measure that alarmed and enraged the Protestants for obvious reasons and others on the grounds of foreign political interference. The reform of the bishoprics and the control that the Crown sought to exercise through them strengthened the resolve of the aristocracy, traditionally favoured by the status

\footnotetext{
${ }^{7}$ In fact, these subsidies accounted for more than $60 \%$ of income (Tracy 1985, pp. 30-31).
} 
quo, at the same time that a number of leading families were replaced by the king's men, thus generating a widespread concern about the reproduction of this social group through the two usual channels, the Church and the court.

In this context the decisive external factor would be, as in France and England, religion. Calvinism, gaining strength over the previous years, unleashed a conflict across the Low Countries in 1566 whose intensity would previously have been unthinkable. The repression enacted by the duke of Alba, together with his efforts to introduce the alcabala, gave even greater strength and impetus to the movement (Maltby 1983).

The result of the conflict would be a society very different from its predecessors, in which the division between North and South was clearer.

In the southern provinces, existing economic growth would be slowed down. ${ }^{8}$ The role of Antwerp in the international economy would be temporarily reduced. The Habsburgs sought the creation of a semi-independent political entity, in which the patronage of the Crown in relation to the aristocracy was strengthened and with it the chances of reproduction of a dominant coalition more similar to that of France or Castile. ${ }^{9}$ The reform of the clergy served to consolidate the ecclesiastical institutions (Parker 1981, pp. 163-164). But favourable conditions for agrarian development, the advance of the verlagssystem and of luxury industries (a good part of them aimed at the markets of Brussels and Madrid), and the tendency to subsidize the fiscal shortfall from Castile favoured economic growth that would continue until 1650 and which, as we shall see, would be helped by the Habsburg monarchy's increasing expenditures (Van der Wee 1988, pp. $347-351) .{ }^{10}$

In the northern provinces, the outcome of the rebellion was even more positive in economic terms. Despite the leadership of Holland, the United Provinces continued to be a fragile confederation and did not even establish shared fiscal apparatus (Israel 1995, pp. 276-306; 'T Hart et al. 1997).

\footnotetext{
${ }^{8}$ Van der Wee and Blomme (1994). The same impression is gained from the population figures or the coefficient of urbanization of the whole area (De Vries 1984, p. 46; Van der Wee 1978).

${ }^{9}$ The previous explanation can be seen in Janssens (1998) and Degryse and Janssens (2005).

${ }^{10}$ According to the figures of Van der Wee and Blomme for Brabante and Flanders, the growth of income per capita may have accelerated to $0.22 \%$ between 1610 and 1660 (1994, p. 91). For the evolution of the urban population between 1550 and 1650, see Klep (1988, p. 267).
} 
But war-and by implication the external threat-together with Calvinism and republicanism, provided the mortar that would bind this society together above the pacts among the elites that were very different from those of France and Spain. Moreover, the clamour of war was assisted by a genuine financial revolution. Although no central bank was created (as occurred in England after 1688), the representative assemblies were able to control the cost and central budget, something which served to increase confidence in the public debt and the state's ability to generate income through the sale of bonds (Tracy 1985; and 'T Hart et al. 1997). Within the space of just a few years, the renten were being sold at interest rates lower than those of the juros of Castile (Graph 4.2a and c).

Obviously this society was not immune to a degree of political corruption or the practices of rent-seeking (Adams 2005). But the scope for the noble classes and merchant patricians to make use of patronage at the expense of the state was reduced. Intensive agriculture, commerce, global expansion through the VOC and WIC, and the export of artisan goods were the only way out: these were, above all else, the bases for the country's prosperity. In fact, the trading companies implied a different model for the devolution of functions. These were institutions that obtained delegated sovereignty from central power. But they were semi-private institutions that lived by their own capacity to obtain investment and impose themselves upon international markets and not by the udders of a state that captured and redistributed funds from the kingdom as a whole. The key to mercantilism was set down in this way (Adams 2005).

Italy cannot be approached as a whole in economic, social, or political terms. It was, with the Low Countries, the most highly urbanized zone of Europe, and the poly-nuclear growth of the century would only serve to reinforce this tendency. But it had one of the most solid seigneurial systems in Europe. This was the case in both 'republic states', such as Genoa, Florence, or Venice, and dynastic polities, such as Naples, Sicily, and Milan. Even in the Papal States, the cities and nobles exercised jurisdictions over large seigniorial estates. In the merchant republics, such as Genoa and Venice, the capacity to exercise jurisdiction through their central administrations had been one of the keys to the success of the merchants and financiers (Greif 2006; González de Lara 2008). In all districts political control and the incomes that they generated were crucial to social success and to the capacity for reproduction of both the urban patriciate and the aristocracy (this was the case even if, as in Genoa or Venice, this had a financial basis).

As in all of Europe, the problems of falling salaries, poverty, the rising cost of land, and farm evictions were evident across the Italian Peninsula 
(Braudel 1976, vol. I, pp. 602-604). And not a few problems originated in the rigidities of feudal rents, the need for expansion of the lineages, and the social ambitions of the patricians. In the South, banditry, nurtured in part by the local nobilities, was increasingly noticeable, and the rising levels of debt began to be a feature of the existence of many families (Villari 1973; Cancila 2013). This tension was also evident within the commercial and financial aristocracy of Genoa, where the fight between the nobili nuovi and nobili vecchi in 1575 laid bare to the world the conflicts originating in the dynamism of these elites (Savelli 1981). War and the demands of the Habsburgs accentuated the instability at crucial moments.

Italy, however, would witness the reproduction of the basic institutional framework. Religious stability, closely tied to the presence of the papacy, was doubtlessly one of the key factors in achieving this. Political fragmentation and the abundance of small states meant that social and political conflicts retained a predominantly local character and were controlled by the local oligarchies or by the Habsburgs, who presided over key territories.

The incorporation of a number of these states into the Habsburg domains had a destabilizing effect at a number of specific junctures. However, in the long term, it facilitated the survival of the social structures. The southern nobilities of Naples and Sicily, indebted and beset by problems of one sort or another, benefited from the patronage of the viceroyal courts (Muto 2005, p. 93; Galasso 1994). This also allowed them to form ties with the leading Castilian and Aragonese families, without doubt the most stable in Europe, and thus to secure a share in the political and economic capital which was to be the basis of the consolidation and extension of the elites (Muto 2009). This tie was also evident in the case of the Genoese families who provided financial services to the Habsbourg and discovered a form of social expansion - and, indeed, even ennoblement was possible in Castile-even if this meant exchanging financial capital for political and social capital in Madrid. Yet the court was not the only space within the monarchy that served this purpose. From the beginning of the sixteenth century, a tendency was established of marriages across frontiers within Italy or with French or imperial families; families such as the Gonzaga, the Colonna, the Visconti, the Spínola, and many others fully took advantage of such practices in order to enhance their power (see the case of Savoy in Osborne 2002). The proximity of the papacy and the Curia, whose membership was fed by these families during the century (Po-Chia 1998; O'Malley 1981), exponentially increased their capacity to overcome their own conflicts and accede to the immense possibilities of patronage that the papacy and the Curia offered (Donati 1995, 
pp. 250-257). The Habsburgs (in Madrid and Vienna), the Church, the empire, and even France offered local patricians and oligarchies the chances of stability and social advancement that were so important to them. The case of the Genoese nobili nuovi who were able to gain access to the financial services of the Habsburg empire is just one example. Their functions for the monarchy were considerable (Arrighi 1994, pp. 127-129).

The corollary of such service to the Hispanic monarchy was the enhancement of seigniorial jurisdictions and urban estates (in some cases, this took the form of the city-state) in many regions of Italy, something which went hand in hand with decentralized principles of enforcement. It is also evident that the development of the economy of legitimation in Florence, Rome, Genoa, or Venice would bequeath to humanity some of Europe's most superb examples of conspicuous consumption and artistic creation. This was not an obstacle to investment in the repopulation of territories in Sicily or to subsidizing those in Lombardy. But it would end by creating rigidities in the productive system. Nevertheless, these developments did not disturb the Italian Peninsula's complex political mosaic, which remained intact, as, indeed, did the jurisdictional fragmentation of each of these political units; at the same time, an urban industrial system with a marked corporative element was consecrated.

To the extent that the prosperity of the elites of Italy was founded upon providing financial services to the great powers, or in the vitality of the artisan sector of the cities, economic growth would continue to be noticeable. But the political and institutional evolution of the peninsula strengthened forms of political economy that were to be less efficient in the very long run.

\section{GLObALIZING Agents}

The world of 1600 was very different from that of a hundred years earlier, and globalization itself was changing.

\section{Informal Globalizing Networks}

Looking at the world in 1600-1630, what is striking is how it had generated forms of integration, control, rejection, and even ecological imperialism that would affect the European political economies in a decisive way. Primitive globalization came hand in hand with the development of informal transnational networks, often based upon what Granovetter (1973) 
called weak ties, which, if not necessarily Eurocentric, certainly would be decisive for the history of Europe.

From the sixteenth century, a process of Catholic renovation, in Po-Chia's phrase (1998), took place. It was to have a global dimension. The arrival of the Spanish in America and the Portuguese in Africa provided the framework that allowed for the global enlargement of the religious orders in particular and the Catholic religion in general. This process, whose only parallel in western civilization is found in the events of the decades following the life of Christ, was just another step in the expansion of medieval Christianity, including not only the continuation of the Reconquista, the eastward expansion of German society, the conversion of Northern Europe and Russia, and the movement known as the crusades. From the fifteenth century, the religious orders were active in Africa, following the Portuguese lead, the Atlantic, and, from 1500, America and Asia. Dominicans, Franciscans, and Augustinians from all Europe found a vast area of evangelization in America. They learnt languages, changed cultures, created forms of religious syncretism that attracted the indigenous populations, and introduced 'civilization' (often in a violent way). ${ }^{11}$

The Council of Trent and the Counter-Reformation accelerated this process. The Jesuits were already in the Orient. But now they began to attach themselves to the centres of power in Japan and China. (Céspedes 1990; Po-Chia Sia 2010). In spite of their recent ubiquity in current literature, they were really very few in number and came above all from Iberia. In parallel, the Augustinians expanded into the Philippines and South Eastern Asia. The establishment of the Spanish and Portuguese empires came to be inextricably tied to the expansion of the secular church and a network of ecclesiastical institutions that, like the monasteries and convents of the religious and missionary orders, established the nodes upon which systems of communication, cultural transferal, and hybridization would be based. These networks served to move persons and even-as the letters of the Jesuits illustrate well-dispatches, news, reports, and books. They advanced the cause of cultural integration and created and circulated images and stereotypes about different areas; in some cases they even led to the rejection of recurrent ideas and descriptions (Gruzinski 2004). These networks were even used to spread formulas for religious homogenization and cultural control, as was the case for the Inquisition, which was soon to

${ }^{11}$ The literature is vast. See, for example, Disney (2009), Boxer (1969), Russell-Wood (1992), and Parry (1990). 
become a global institution (Bethencourt 2009). But, fundamentally, these networks, persons, and institutions retained a large margin of manoeuvre with respect to the monarchs' temporal power and, to be specific, to the Spanish imperial structure of Philip II and his successors, despite the kings' attempts to control them. European expansion was therefore marked by something that has often passed unremarked. Despite the proximity of temporal and spiritual power, it was based upon a dualism of powers, the spiritual authority of Rome and the temporal power of the monarchs. For all the involvement of the latter in the appointment of bishops and the exercise of patronage, this was to be a lasting and important dichotomy.

Catholic expansion did not come alone, nor did it represent all of the agencies involved in the process. Very shortly the Protestant societies created in North America their own nuclei of expansion. At the other extreme of Christendom, the Orthodox Byzantine Church was involving itself in Russia and the oriental frontiers of Europe. The same could be said of Judaism, whose development and expansion can be linked to the continuation of the process of expansion. These years witnessed what J. Israel called the 'revolution in Jewish life', 'the decisive change'. Spread across all of Europe, and often boasting Spanish origins, the Jews knitted together dense networks of cultural and commercial relations. Faced with attempts to contain them, these networks expanded into America and Asia (Israel 1985). Meanwhile, the expansion of Islam through Asia, towards Indonesia, the Philippines, and Malacca, and along Africa's east coast, the Sudan, parts of Ethiopia, and Indian ocean would continue throughout the century, being closely linked to the growth of Muslim commercial networks in these areas (Céspedes 1990, p. 57). It is also worthwhile remembering that, if religious identity formed the basis of these systems, these networks were the ideal stage for agents and mediators whose influence was not confined to a confessional programme. Once the contact among different cultural worlds was established, these agents transmitted many different types of messages (Cools et al. 2006).

To the extent that the Iberian empires became a platform for the internationalization and globalization of their elites, these institutions reinforced a process (mentioned above) that saw the emergence of global networks. And this process was more intensive from 1580. As occurred with the religious orders, this phenomenon was not limited to the relations between the metropolis and the colonies. As it also projected itself upon Europe as a whole, it bound the old continent and the New Worlds together in inextricable ways, with the areas of the south of Europe being especially affected. 
These trends were not confined to the elites. According to official figures, about 130,000 Castilians emigrated to America between 1500 and 1580, many of them artisans (Romano 2004, p. 64; Martínez Shaw 1994). As their correspondence clearly demonstrates, these globetrotting elites took with them many servants and maids, members of their retinues, and even their friends and relatives belonging to the lowest social strata, all of whom contributed to creating global ties at all levels of the social hierarchy. And, importantly, the correspondence and testamentary records also show that many did not break entirely with the peninsula but rather maintained genuine links and networks (Otte 1986; Redondo and Yun 2008). Military officials, technicians, miners, and sailors, who had been trained in Europe, found in America, Asia, and Africa an area of action and even a theatre into which they could introduce and spread their knowledge, cultural habits, patterns of consumption, and so on (Centenero 2009, Altman 2000, Yun 2012). The 'oceanic world' (the Atlantic) was populated by slaves from Africa, many of them blacks, who, at the end of the sixteenth century, were already numerous in the Caribbean (as is widely known, New Guinea acquired its name as an allusion to the origin of its population). What is less well known is that they often lived side by side with Asians, some of whom were also slaves (De Sousa 2015). A respectable community of Chinese existed in Puebla, fed by Jewish merchants who forged links in Asia and the Philippines (Altman 2000 and Seijas 2014). This case provides a study of social groups who rapidly lost contact with their original societies but who were highly active in the process of cultural cross-fertilization and globalization that marked this period.

Commerce and merchant networks were especially active in the forming of this mesh of social and cultural agents. In spite of the attempt to control migration by the Spanish Crown, Italian families-above all the Genoese-followed their Castilian and Portuguese counterparts in expanding into America, often retaining a transnational component that defies any narrow national or political description (Subrahmanyam 2007; Bethencourt 2013; Kellenbenz 2000). By the mid-seventeenth century, the mixing of Europeans of very different origins was so advanced that contemporaries were unable to differentiate among them. This is what happened, for instance, in the Río de la Plata (Trujillo 2009), where Castilian and Portuguese groups settled. The last decades of the sixteenth century saw the flow of Portuguese businessmen into Brazil and the extension of their activities towards Argentina, whose direct connections with Africa consequently increased (Boyajian 1983). The entrance of the 
Dutch, and subsequently the English, into the Caribbean and Asia is a symptom of this mercantile globalization (Boxer 1965). At the beginning of the seventeenth century, French skin traders made contact with the Iroquois and Huron in North America (Curtin 1984, p. 226).

This global expansion is just another manifestation of changes occurring in the old continent. Here the Jewish commercial diaspora drew in communities stretching from Poland to Central Europe to the Near East (Israel 1985). The Jews of the Low Countries strengthened their links with Lisbon and even with Burgos; from Lisbon they extended their ties with Italy (Ruspio 2007). In the other extreme of the commercial network, in the Mediterranean, "the "Spanish Jews", spread out through Salonica and Constantinople, or through Ragusa, Split and Valona, taking control of the commercial routes of the Balkans' (Israel 1985, chapters I and II). The English, meanwhile, were increasingly active in the Eastern Mediterranean, in Venice and Greece (Fusaro 2015), and even in Safavid Persia. The Genoese could be found across the Habsburg territories, and families of noble financiers, such as the Spínola, the Gonzaga, and others, even established French and Austrian branches. During the second half of the century, the Flemish presence in Seville increased, while Italian activities in distant areas such as Gdańsk were growing (Samsonowicz 1973 , pp. 538-539).

The ensuing and expanding webs of individuals displayed characteristics that are worthy of consideration. The first of these is that the political frontiers of empires were no obstacle to these personal connections. This would be more and more the case, as the analysis of Portuguese and Spanish empires (below) will show. But, perhaps more interestingly, though the different groups defined their particular identities according to their origin, religion, and family links, it is impossible to describe them in terms of 'national' networks, even in the case of Europe. This mixing of 'nations' was equally present within the old continent and was projected upon it. A Valencian noble family that achieved fame in Rome, such as the Borgia (mentioned above), demonstrates this point if we consider its American branches (Redondo and Yun 2008). The same could be said of the Corzo and the Mañara, both of Italian origin, that established deep roots in Castile and extended their reach into America, which in turn became decisive for their businesses (Vila 1991). In other words, these were not 'national' networks spread across the globe but rather a globalization or extension across the world of Europeans who, in many cases, were often already involved in 'transnational' practices. Some scholars 
might argue that Henry Kamen perhaps exaggerated in his interpretation, in which the Spanish empire emerges as not exactly Spanish (Kamen 2002). Nevertheless, an undeniable sociological basis sustains this view on, although the empire was far from singular in displaying these traits.

\section{European Integration}

Around 1600, these global networks served as channels for the transferal of products, patterns of consumption, and ways of life-and also for their combination and rejection (Yun 2014b). This reality was to have important effects on the economy. The population of African and European origin, as well as their mix with the remaining Amerindians, also grewmeaning both mestizos, the offspring of Spanish men and Indian women, and mulatos or 'mulattos' of black and white parentage. As a matter of fact, these groups grew in size during the sixteenth century and continued proportionally to do so in the following century, while the Amerindian population practically stagnated between 1600 and 1700 and so lost weight as a percentage of the total. ${ }^{12}$ Obviously, the type and origin of a population cannot be identified with its norms of consumption. But, this having been said, it is evident that if this remained a small population in comparison with that of Europe, the number of inhabitants who sought goods and products from the old continent was growing, while demand for hybrid commodities and wares was also gradually increasing. And we should also remember that, aside from the 'whites', 'blacks', 'mestizos', and 'mulattos', the native Amerindian population was also adapting its patterns of consumption. Looked at from the perspective of the circulation of products moving in both directions, it is clear that, together with the extension of

\footnotetext{
${ }^{12}$ It has been calculated that around 1570-1600, Latin America had approximately 10 million to 10.2 million inhabitants (Romano 2004, p. 61), around 25\% more than the Iberian Peninsula. Of these, the whites accounted for around 130,000 (between $1.2 \%$ and $1.3 \%$ ); blacks, mestizos, and mulattos probably came to $260,000(2.3 \%-2.5 \%)$ (Konetzke 1976, pp. 92 and 93). The rest, 9.8 million (95\%), are Amerindians. By 1600 some 120,000 African slaves had been transported, and European emigration had reached 139,000 to Spanish America and 93,000 to Brazil; these figures reached 188,000 and 110,000, respectively, between 1580 and 1640 (Curtin 1969; Romano 2004, p. 64). By 1650 the black population had reached 830,000 , the mestizos 400,000, and mulattos 269,000; the Amerindian population had fallen to $9,175,000$, while Europeans had risen to 730,000, a considerable increase in both number and proportion (Konetzke 1976, pp. 92-93).
} 
informal networks (in reality, both developments were part of the same phenomena), the empires began to promote patterns of consumption of a globalizing character (Kupperman 2012). This process was not easy, being marked by rejections, and often depended upon processes that were not purely economic in nature (Yun 2012). The diffusion of non-American patterns of consumption and hybridization was very often manifested in cultural, rather than commercial, processes and even in violence, which tended to follow in the footsteps of mercantile dissemination (Yun 2012). But, all in all, networks formed in this way accelerated the commercial relationship between the different areas of the New and Old Worlds. And this came at the same time that the presence of Europeans, and the processes of conquest and internal emigration associated with them, invigorated the spread of local American products (Saldarriaga 2011), and the arrival of Asian products also increased (Gasch 2014).

America began to export dye products, sugar, leathers, and other goods; true, the scale of this trade remains difficult to assess due to smuggling, but without doubt it grew from the middle of the sixteenth century and-something not to be overlooked-underwent diversification. Something similar was happening with the Asian trade controlled by the Portuguese and, increasingly, the Dutch, which also diversified. Pepper was followed by other spices and products, such as silk and cotton, indigo, clove, and nutmeg, among others (Boyajian 1993, p. 44 and passim). The processes ran parallel to the intensification of Atlantic commerce-and in particular of African trade-with America and Europe. Not only did the trade in slaves expand, but so did the trafficking of exotic products, fish, wine, grapes, dyes, ivory, and many others. And this was matched by the exportation of European products to Africa, with zones such as Morocco, Senegambia, Sierra Leone, Benin, and the Congo benefiting, while the commerce between the Gulf of Guinea and Brazil grew in vigour, and the Río de la Plata became more active (Russell-Wood 1992, chapter IV).

These ties not only brought distant continents closer together, but they also had a special effect upon trade within Europe. The result was a greater interconnection between the European economies. The evolution of urban networks is perhaps one of the clearest indirect indicators of this. It did not, of course, simply reflect the impulses of international trade. On the contrary, these links were closely tied to agrarian development and increases in local productivity that allowed for the emergence and advancement of urban industry. But it is very interesting to remember that around 1600 , the process of urbanization was creating 'a unique urban hierarchy 
that was going to begin the fusion of the numerous European systems of urban' development (De Vries 1984, pp. 126-128). And even more important, between 1600 and 1650, a Europe-wide model of urban development was established that was increasingly linked to the advancement of the coastal zones and in particular to those of Atlantic Europe that were most closely connected to colonial commerce. If this cannot be considered to be the only cause of this change, it is evident that this was a factor in it.

The increase in the global circulation of silver gave further impetus to this process. As Attman (1986, p. 35) wrote, 'the enormous quantities of precious metals that the Spanish empire in America transferred to Europe ... were of the greatest importance for global commerce'. ${ }^{13}$ The development of commercial techniques and the means of payment, as well as the increasing speed of transmission of commercial knowledge, had positive effects (Van der Wee 1978, pp. 306-332). Financial techniques developed in the south were adopted in the north, which hitherto had lagged far behind. As a result, deposit banks proliferated. The ricorsa, endorsement of a bill of exchange, became an even more common practice among the leading European businessmen (Van der Wee et al. 1991). The development of the printing press led to the dissemination of treatises on commercial techniques that facilitated the circulation of information on weights, measurements, and book-keeping or accounting, with similar effects (Hoock and Jeannin 1991, pp. 373-382). The expansion of insurance techniques was helping to reduce risks and transaction costs. Business networks further advanced these changes, lowering the costs of both transaction and information and making it possible to circulate goods between ever-more-distant centres. This was important for the extension of commerce into markets as imperfect and as different as those of the time.

If qualitative improvements in land transport remain difficult to pinpoint, it is very clear that ever-larger quantities of livestock were used, with the number of mules in particular increasing (Braudel 1976, pp. 375-376). Changes were also manifested in the growing repertoire of roads and journey routes; the inn system was improved, as were the available descriptions

${ }^{13}$ The European net monetary stock had passed from some 1021 tonnes of silver equivalent in 1570-1580 to around 2510 in 1590-1600. In this way the monetary mass in silver had multiplied by 2.5. Calculations are based above all on Morineau (1985, pp. 581-583) and obviously are very tentative. They do not take into account, for example, the melting of gold and silver to produce jewellery, which undoubtedly rose in this period. 
of regions and roadways (Maczak 1996, pp. 37-53). But the most relevant changes took place in maritime transport, something which would be important in the displacement of the great axis of the economy towards the littoral zones in general and those of the Atlantic in particular. The pioneering techniques of naval construction of the south were spread across Europe and adopted and improved. In Holland this process led to the reduction of the sailing time between the Baltic and Spain; it also led to an increase in the size of the ships and their holds (De Vries and Van der Woude 1997, pp. 355-357). Other significant improvements continued to be made in the instruments of navigation and cartographical representation (Parry 1990, chap. 6). Oceanic navigation improved thanks to both institutional and organizational planning, developments that were manifested in the application of the sciences to the training of sailors in institutions such as the Portuguese Casa da Índia or the Castilian Council of the Indies (Chaunu 1959; Schäfer 2003). In the second half of the century, galleons and ships began to replace the old caravels, and both the number of merchantmen and their overall tonnage increased dramatically (Chaunu 1977, pp. 242-243 and 271). Writing of the Portuguese case, Godinho speaks of a recession after the crisis of the mid-century (1982-1987). But it is probable that the increase in the size of design of the ships soon compensated for this contraction to the extent that the highest figures of the century were registered in the decade 1581-1590 (Duncan 1986, pp. 3-25). This conclusion is strengthened if we take into account the upward trend found in the toll registers of both Malacca and Ormuz (Subrahmanyam and Thomaz 1991, p. 313 and passim). In this context it is not surprising that recent research on Portuguese cultural and political history in this period has moved from speaking of a 'crisis' to a 'reformation' of the empire (Barreto 2015, chapter 1).

By 1600 the growing quantities of spices (already a well-established phenomenon) and new colonial products arriving in the Old World were having a dynamic effect on other branches of trade. By this point European consumption of classical spices (pepper or products such as sugar) was rising, and new colonial products were bringing about changes in European (mainly European elites) patterns of consumption. ${ }^{14}$ At the same time, the circulation of those products within Europe was encouraging new return

\footnotetext{
${ }^{14}$ The global production of sugar would rise thanks to the establishment of sugar refineries in Brazil, where output went up from 60 in 1570 to 230 in 1610 (Bennassar 1980,p. 158) and from 180,000 arrobas imported in 1560 to 600,000 in 1600 (Phillips 1990, p. 56). See also Mintz (1986).
} 
trade routes between diverse regions and, with them, international market integration. Around 1567, for example, the imports of Spanish cochineal or Portuguese spices and sugar were already worth around half the overall trade between Spain and Portugal and the Low Countries (De Vries and Van der Woude 1997, p. 360). This commerce stimulated a reciprocal trade in other products, some traditional such as Iberian salt, and even reinforced return sales from the Low Countries, whose costs of distribution fell in line with the growing commercial complementarity between these two regions. All of this trade united with the inverse tide of merchandise that paid for the flow of Spanish silver towards the north of Europe.

It is not, therefore, surprising that even those scholars who have denied the existence of a 'revolution in transport' (understood as a continual reduction in costs from 1300 to 1800) have underlined the importance of the fall in freight costs in European commerce between 1550 and 1600 (Menard 1991, pp. 228-275).

All of these developments lead to a point for reflection. The process described above implied a long-term movement of merchandise that remained at a very modest level in terms of the GDP of the countries involved in it-above all Italy, Spain, Portugal, France, the Low Countries, and England. Moreover, the extent of American demand for European products should not be exaggerated compared to present-day standards. At the same time, it was a twofold phenomenon. The size of the white population in the Americas in 1600 (120,000-130,000) was not much greater than that of a city like Seville, which, as we said, still did not entail a big market for European products. But, on the other hand, that population grew to 730,000 by 1650 . This is to say that during the first decades of the seventeenth century, America was still a relatively modest market but also an extremely expansive one. The outcome was clear: on the one hand, there existed ferocious competition for the control of this market on the European side, which can be fully understood in light of the colonies' high purchasing power; on the other hand, the market was already too large and dynamic for the countries that sought to monopolize it, Spain and Portugal, to be able to do so with their domestic production. And this situation leads to another consideration: despite the reduced size of this 
market and even of overall colonial commerce, its impact on the European mercantile economies would be quite significant. In fact, this expansion of international commerce and globalization brought with it the possibility that the more flexible and efficient economies would impose themselves upon the more rigid and weaker ones and also paved the way for increasing political and economic tension among Western European polities. In this context the impact of religious wars and the circulation of silver within Europe, partially associated with Spanish expenditure, would be crucial.

\section{Habsburg Wars, American Silver, and the European Trends}

In many ways the Spanish and Portuguese empires provided the crucial machinery for the transformation of the European economies.

Before 1566, when the rebellion of the Low Countries first broke out, the Habsburg wars had led to a concentration of war spending outside the peninsula. Moreover, the intense commercial relationships with the north and the Mediterranean also encouraged the flow of silver to these areas and the greater connection between them (Chap. 3). But these developments assumed hitherto unsuspected dimensions from the decade 1560-1570 thanks to the 'War of Flanders' (as it came to be known in Castile) and its tendency to drain away from Spain the silver brought in by the second cycle of American precious metals (Chaunu 1959).

It is important to emphasize that most military spending on the Iberian Peninsula was concentrated 'on the periphery' and, specifically, in the areas of Catalonia, Navarre, Gipuzkoa, Aragon, on the French frontier, Andalusia, Portugal, Galicia, and the Cantabrian coast (Thompson 1992, II, p. 11). The flow of silver in the form of military expenditure into these regions favoured their incorporation into the international commercial routes, the case of Catalonia being a good example (Vilar 1962). In this regard, the case of Portugal is also demonstrative. The increasing role of the Portuguese in the development of the commercial centres of Castile ensured that the Portuguese economy came to depend upon that of its Iberian neighbour and American silver-as well as Castilian currencyflowed in growing quantities to Portugal (Disney 2009), so affecting this economy and enhancing its links with international routes. It is worthwhile taking into account that part of the cost was spent on imported commodities, such as the woods of the north for ship construction, iron, and other goods.

But, moreover, the foreign wars of the Habsburgs affected, in a broad sense, the economic relationships between these areas. 
Antwerp's fall was not a sudden one, as has often been claimed (Van der Wee 1963). But, this having been said, there can be few doubts about the negative effects of the conflict on the southern provinces of the Low Countries (Parker 1979, pp. 177-179). It was, moreover, exacerbated by a number of related developments: fiscal pressure was intensified, and the blockades imposed by the Sea Beggars affected another pillar of the Antwerp economy, its links with the south of Europe. The overall result was the dislocation of the system that had been so effective until the $1560 \mathrm{~s}$ (Van der Wee 1963). English cloth would henceforth be directed towards other areas, and German commerce would flow towards the Hanseatic ports. Portuguese spices and Castilian wool would also be temporarily withdrawn from the Flanders route (Phillips and Phillips 1997, pp. 254-255). The trade of Lyon with Antwerp was also adversely affected by the French wars of religion and the shift of a range of Flemish industrial activities towards France (Van der Wee 1963). Antwerp's links with Italy were reduced by the fall in the overall volume of cross-continental commerce and the new links emerging between the subalpine peninsula and Castile, thus reorientating towards Iberia a significant portion of the shipments which previously had been sent over the Alps.

This succession of reverses would also affect the northern provinces of the Low Countries, although in this case the consequences were positive. Trade between Holland and the Baltic was negatively affected from 1569 , confirming the difficulties facing the region and the deleterious effects of war (De Vries and Van der Woude 1997, pp. 363-364). Philip II's embargoes on Dutch trade had a short-term impact, in part because from 1580 he was able to use Portugal against the northerners. The war effort forced the rebellious provinces into a fiscal policy (resulting, inevitably, in higher taxation) that, (again) in the short term, had negative consequences on its economy. ${ }^{15}$ Yet the downturn was only temporary. From the last years of the 1580s, the recovery of Dutch commerce and industry became evident. The destruction of the Spanish Armada, including many merchantships, made the Dutch indispensable in the Spanish traffic between Northern and Southern Europe at precisely the moment when they were reestablishing their influence in the Baltic, where they gained a foothold in the routes to Asia through Archangel; Spanish silver was, of course, vital

\footnotetext{
${ }^{15}$ Between 1552-1560 and 1588, fiscal pressure, measured as a percentage of an unskilled worker's salary, increased three-fold in Holland. The scale of this change was unique in Europe (De Vries and Van der Woude 1997, p. 97).
} 
to Dutch transactions in both the Baltic and Far East (Israel 1989, p. 44). Moreover, a series of poor Mediterranean harvests allowed the Dutch to penetrate into the inland sea, thus offering them access to markets of everincreasing size and value.

As a consequence, Holland and Spain, while still at war, came to find that their respective international economies could not work without each other-this was, in fact, highly significant for the strength of international commerce. Dutch merchants knew that Spanish and Mediterranean markets were vital for the wheat that they shipped from the Baltic; in turn this supply system was rapidly becoming a provisioning lifeline to the cities of southern Spain. ${ }^{16}$ Fish (a staple food during the long Easter of the Counter-Reformation), light cloths (ever more adapted to suit the demands of the sweltering regions of southern Iberia), and other Dutch and Northern European products were becoming more and more soughtafter in Iberia. Dutch shipping was also becoming vital to the export of Iberian goods to the north. In turn Holland needed ever greater quantities of Mediterranean salt, not to forget cochineal and spices from America, Africa and Asia. Above all else, the Dutch depended upon American silver, without which it would have been impossible to pay for their purchases in the Baltic regions and more and more in Asia. Little by little, these demands fed and merged into the Spanish need for Swedish copper with which to mint vellón coins in Castile (coin minting was rising from 1610 to 1620).

But it was not only the trade of the north of Europe that benefited from the flow of silver and the expenditure on war. In Italy the effects were twofold and very complex. The interruption of the axis between Burgos and Antwerp after 1566 caused a shift of the wool trade towards Italy and, especially, Florence (Ruiz Martín 1990a). The emergence of the 'Spanish road', a very narrow strip of territory between France and Germany that allowed Castilian silver to be carried to the northern theatre of arms, reinforced the position of the Genoese, who now controlled the finances of Philip II as never before (Parker 1972). The resultant changes left a trail of silver across northern Italy, whose businessmen were also able to take advantage of Lyon's problems to give impetus to the fairs of Piacenza. Spanish military spending in Lombardy, and the emergence of the Baroque court in Madrid, reinforced that region's connections with international routes (Braudel 1976; Sella and Capra 1984, pp. 109-115). American

\footnotetext{
${ }^{16}$ See the case of in Seville in Cámara de Castilla, Libros de la Relación, lib. 23, pp. 293 and ff. AGS.
} 
silver flowing towards Italy must have been a positive factor for the integration of the regional economies of the Italian Peninsula's many states. Links such as those between Genoa and Naples or Sicily were strengthened by the purchase of large estates in the Mezzogiorno by the great merchants and bankers of northern Italy, who saw them as a means of investing in guarantied incomes and a way of acquiring wheat that could later be sold in the Mediterranean (Delille 1988). In Venice these changes coincided with a new flow of spices exchanged for silver in the Mediterranean and a general increase of Venetian participation in commerce from Sweden to Poland. This trend coincided with an increasing volume of trade from the Eastern Mediterranean areas to Asia through Safavid Persia.

War and silver, two phenomena that were always difficult to separate and were linked to the global broadening of economic and political relations, were becoming relevant to both the functioning of the European international economy and changes in it. These flows of silver sparked inflationary tensions in Northern Europe. But they also resulted in a proliferation of the means of payment, and this was beneficial to economies characterized by a strong commercial sector (at least, by the standards of the age).

By this time the trade between Holland and the Iberian Peninsula was restored, in spite of the increasingly ineffective attempts to impose a blockade. Annual transfers to the Low Countries grew to almost 4,000,000 ducats (Thompson 1976), meaning 1.4 ducats per capita each year. To this figure should be added the profits from commerce with Spain in the 1590s, when Dutch and Flemish merchants (the former illegally pretending to be Flemish) expanded their activities, mainly in Andalusia. The strength of economic links between the north and the south of Europe had become so important that the city of Seville itself complained about the reprisals, both fiscal and military, to which these 'nations' were subjected. Contraband and smuggling were the inevitable manifestations of this desire to trade (Gómez-Centurión 1988, pp. 257-317). ${ }^{17}$ And though we do not have precise figures, we can assume that these activities sparked sectors of the Northern European economy and enhanced the international links between the different regions, thus smoothing out the negative

\footnotetext{
${ }^{17}$ No reliable figures can be given, but a memorandum on the import tolls of Seville put the value of the products unloaded at the docks between January 1593 and April 1595 at some 3.6 million ducats (Gómez-Centurión 1988, p. 295)—almost 1.5 million ducats each year, a figure that represented no more than the tip of the iceberg, given the level of smuggling and fraud.
} 
effects of many political events. To a lesser degree, the new situation was also perceptible in the north of France. Here the arrivals of Spanish silver and the expenditure inherent to it were lower: 2.8 million ducats per year, according to Attman, which meant just 0.14 ducats per inhabitant or $1.8 \%$ of the agrarian product in 1588 (Morineau 1977, p. 979). Before the 1590s the positive effects of this commerce with the southern Netherlands had begun to be felt in England. From the 1540s trade with the Iberian Peninsula had remained relatively resilient; at the very least it remained stable and was perhaps growing, buttressed by the foundation of the Spanish Company (Brenner 1993, p. 12; and Croft 1989). Again, war and embargo did not have a genuinely tragic impact, and so vital were these trade lines that rivalries emerged between the merchant groups who operated in the Spanish Netherlands and the Merchant Adventurers, who traded in the Dutch provinces and claimed the right to control both routes (Croft 1989; Brenner 1993, p. 15). Another spur to commerce came with the foundation of the Turkish Company, the Venice Company, and the Levant Company, all of which took advantage of the growing connections of Spain with the Mediterranean and the experience of English traders in the Iberian Peninsula (Brenner 1993, pp. 16-23). After the disaster of the Invincible Armada, this activity grew quickly and even encouraged a greater interest in Atlantic commerce. ${ }^{18}$ Two vital characteristics of this trade should be underlined. First, it was increasingly in the hands of the English themselves, meaning that an increasing proportion of it fed back into the domestic economy. Second, this trade was based not only on the expansion of the market for English products in the south of Europe but also on the importation of raw silk, woven Italian silks, spices coming through the Mediterranean, raisins from Greece, and American products (Brenner 1993, pp. 25-27).

The process - very much linked to the first globalization-in which Spain's foreign policy and economy served to spark commercial links elsewhere was even more pronounced in Italy. Here political and financial events came to oxygenize the economy, ensuring that many regions enjoyed a significant scope for expansion and their connections to international trade and finance were enhanced. The victory of Genoa in the financial battle for Madrid, and the continued vitality of the Piacenza fairs until 1621 , meant that the Genoese maintained 'control over the world's wealth

\footnotetext{
${ }^{18}$ See Brenner (1993, pp. 26, 17, 30, 45-50) and Gómez-Centurión (1988, pp. 241-255).
} 
for a long time' (Braudel 1976, vol. I, p. 671). This was despite the Spanish royal bankruptcies of 1596 and 1607. The need to feed the Spanish road also had a crucial impact on Italian trade with Europe for a long period (Parker 1972), and, as we shall see, it also benefited its industry until at least the 1610s. ${ }^{19}$

Several decades of warfare therefore favoured the redirection of trade networks in different areas of Europe. More importantly, the Habsburg empire and the first primitive globalization with their two main features, war and silver, had exerted a strong impact in enhancing a number of specific trade connections. Such connections were often interrupted but remained resilient and vigorous in the long term. But to fully understand their different histories, we need also to consider the local conditions and the political economies and institutions in which war and silver expenditure were acting.

\section{The Gradual Shift to The North}

The ways in which different countries faced the challenges and new international economic context at the end of the sixteenth century would be decisive. But this depended upon their respective political economies and upon the endowment of productive factors, the position of each country in the international economy, and their capacity to compete in more integrated markets. Competition among them also had become increasingly decisive on account of this process of economic integration that bound the areas of Europe and those of the rest of the planet.

\section{0: The Problems of Europe}

In order to understand the consequences of this competition among economies, it is, however, important to consider the context that gave rise to it and the general problems facing them.

If regional differences were very marked - more so, indeed than national ones-by 1600 European society as a whole was facing a problem of

\footnotetext{
${ }^{19}$ Figures given by Parker leave no room for doubt about the relative importance of Italy in the payments made by the monarchy. If 11.7 million had been spent in Flanders between 1571 and 1577, some 7 million had been invested in the Mediterranean fleet, a considerable sum (Parker 1972, p. 232-236).
} 
resources. The rapid increase of population (from some 80 to 100 million inhabitants from 1500 to 1600) and the accelerated rhythm of urbanization created evident Malthusian and provisioning tensions in Italy (Braudel 1976). But similar problems were emerging in France and England, where poor harvests and epidemics began a cycle of hardship that would last until 1630 (Wrightson 1982, pp. 122-123, and 142-148). ${ }^{20}$ Even in the Low Countries, characterized by a form of highly intensive agriculture by the standards of the time, growth was based upon the extension of cultivated land (De Vries and Van der Woude 1997, pp. 27-28). And in Brabant it was possible to perceive a certain degree of agrarian stagnation by the 1550s (Van der Wee 1963, pp. 209-213). The higher rates of urbanization of these areas - a trait shared above all by Italy, the Low Countries, and some regions of France and England-created provisioning problems for the cities that sometimes threatened their economies and, in particular, their industrial sectors.

The increase in land rent accentuated this disequilibrium by reducing many peasants' margin of subsistence. To the extent that in many zones of Europe this came on top of a process of property concentration and caused a degree of social instability, it also brought about a number of productive adjustments. Although it remains difficult to measure social inequality, the figures produced by O'Rourke and Williamson on wage-rent relations demonstrate that the period 1500-1600 witnessed the fastest increase in inequalities in the entire early modern period (2005).

Trends in real wages are also downwards in countries such as England or Castile (Yun 2004, p. 425, Graph 7.3). If these figures should be used with caution, since in many areas of Europe cash salaries formed just a part of the incomes of peasants and members of the lower classes, this trend brought with it the permanent danger of reducing the purchasing power of many families. The result was the social uprooting and indebtedness of many peasants (Braudel 1976, vol. II, pp. 117-134). And with this outcome came the danger that poverty, Malthusian tensions, and social inequality would end economic growth.

In the same way as was happening in the Iberian countries, in many other areas, the development of the market and the juridical differences over the form of access to land provoked an increasing divergence within the peasantry. One of its manifestations was the emergence of a genuine

${ }^{20}$ Le Roy Ladurie (1977, pp. 576-585); Clay (1984, p. 126); Overton (1996, p. 79 ). 
'peasant aristocracy', increasingly differentiated from the rest of its community. This change was evident in France and England, where authors such as R. Allen have underlined the growing inequality within the rural community. ${ }^{21}$

The inequality in the distribution of income undermined the chances of maintaining social stability within the rural community. Europe, and above all its cities, became full of poor and migrants from the rural areas (Geremek 1987). This was advanced by certain measures, such as the increase in the power of the seignior or the pressure of the taille and other taxes (Salmon 1975). At the same time, the development of the artisan sector, seldom achieved in direct proportion to the recognition of its political rights, created a number of tensions within the cities (Israel 1995, pp. 119-122, Lane 1973, pp. 318-319.)

The review of the different Western European economies (above) makes clear that tensions were also perceptible within the aristocracy and the seigniorial class. Even in those areas where seigniorial estates had been more resilient, structural tensions arose on account of the diminution of the rate of seigniorial extraction and the increasing expenditures to meet military and social requirements (Bois 1976; Asch 2003). True, European aristocracies were not ruined, as has sometimes been suggested. But this was a group subject to internal changes and in need of transformation. In the final analysis, the class that constituted the pillar of the social order was changing, a shift that, in turn, altered the basic structure of society.

From 1500 the escalating cost of war made everything worse. Historians continue to discuss the validity of the term 'military revolution', first coined by Roberts (Parker 1995). But what is clear is that the dimensions and demands of armed conflicts were growing across Europe, whether we accept a centralization of warfare or not. Bureaucratic costs and the need to feed the pacts of the dominant coalition increased expenditures, while the collection of taxes continued to depend upon highly consolidated local powers.

It is in this context that competition among the continent's different economies would act and be decisive. And this was because in these difficult moments, competition in international markets-including the limited but dynamic American market-would become very tough and crucial for the different regional economies.

${ }^{21}$ Neveux et al. (1975, pp. 134-135); Jacquart (1974); Allen (1992, pp. 66-67). 


\section{The Peninsular Interior by 1590-1600: The Limits of a More Rigid Economy 22}

The model for social development, characterized by the consolidation of the dominant coalition (Chap. 4) that had configured the political economies of the Iberian kingdoms (Chap. 5), would make its impact felt from 1580. If all the Iberian kingdoms experienced similar problems, the impact would be different in each region. The peninsula's heartlands-a wide bank of land running from the Duero Valley to the banks of the Guadalquivir and from the Iberian System to the Alentejo region of Portugal-would suffer the most from this international competition. This was also because, leaving aside other conditions that will be examined below, it was here where the more negative components for economic growth would have greater impact. Since the last decades of the century, the more negative side of the institutional system (Chap. 5) would become predominant in the allocation of productive factors, which would reduce the competitiveness of the economy in a context of epidemic and economic crisis.

\section{Long-Term Changes}

By the sixteenth century, decisive long-term structural changes had taken place in this area. Many of the problems examined thus far for Europe in general were also present here: the tension between resources and population, the rising price of land rents, the fall of urban salaries and the imbalances in the distribution of income, tensions within the aristocracy, fiscal pressure, and so on.

But the situation would become even worse in many ways. The proliferation of entailed properties was reaching a very high level across the Iberian Peninsula but more in particular in this area. This fact is evident not only in the available data series on the foundation of mayorazgos (Yun 2004, p. 277, Chart 5.2) but also in the case studies of ecclesiastical institutions. ${ }^{23}$ This irreversible trend obviously had strong accumulative

${ }^{22}$ The bibliographic apparatus and figures for this section can be seen in Yun (2004).

${ }^{23}$ Marcos (1985, vol. I, pp. 128 and 178); Yun (1987); Mata (1987); López (1998, p. 226); Pérez Picazo and Lemeunier (1984, p. 101). One of the evils of the kingdom, said a royal official (corregidor) of Seville in 1591 in an observation often repeated by the arbitristas, is that 'a great deal of property is being incorporated into the clergy and the religious orders by donations, chaplaincy foundations and the testaments of friars and nuns' (Cámara de Castilla, leg. 716. AGS). 
effects and consequences. ${ }^{24}$ The situation was made worse to the extent that the growth of the incomes of some seigniorial houses and religious institutions was very slow or even saw falls (Yun 2004, pp. 457-458). And all of this was happening while costs were rising and the economy of legitimation was gaining strength, propelled forward by the march of the Counter-Reformation spirit and the demands of court life. ${ }^{25}$

All of this had important consequences. One of them was that a greater proportion of the surface area and a greater share of the means of production were in the hands of the privileged and therefore subject to management criteria that, as we have seen, were now not always aimed at the introduction of improvements but rather at augmenting the reproduction of the political capital of the elites. Consequently, moreover, the rise in the price of land rents - a normal feature of the management of these patrimonies and one commonly employed over the previous generations (Chap. 3)-would affect an ever-larger share of the land surface and reach exhausting quotas. ${ }^{26}$ Some seigniors even proceeded to raise other extractions, including the alcabalas. ${ }^{27}$

As everywhere in Europe, the long-term tendency was towards the polarization of incomes and a growing social inequality. This resulted in a range of consequences, such as inflation, the fall in real salaries, the rise of land rents, demographic pressure, and the shifting of fiscal burdens onto basic consumption goods that negatively affected a large part of the population. The same processes, together with the consolidation of entailed and mortgaged properties and bumper commercial profits, increased the wealth of elites. This phenomenon tended towards more progressive effects on consumption. On the one hand, conspicuous and luxury consumption was developing, tied as it was to the economy of legitimation, court lifestyles, and the double economy of mayorazgos and credit system

${ }^{24}$ See Yun (2004, p. 277, Table 5.2). Some concrete examples in Yun (1987, pp. 254-255), Basas (1994), and Gómez Zorraquino (1987, pp. 147-148). Libros de Relación, 18, 21, and 25 AGS.

${ }^{25}$ López (1990, pp. 79-80); Martz (1983, p. 172); Latorre (1992, pp. 209-211).

${ }^{26}$ Moreover, many seigniors and ecclesiastical institutions had to recur to tougher, more demanding rental formulas that would break with the criteria of the enfiteusis previously employed (Álvarez 1987, pp. 37-38).

${ }^{27}$ A variety of cases can be found in Pérez Picazo and Lemeunier (1984, pp. 98-99), Yun (1987), and López-Salazar (1987, pp. 101-102). The Almirante of Castile's alcabalas exceeded 1.3 million maravedís in 1568 and rose to 5.8 million in 1583-1588 and 6.7 million in 1589-1596. Libros de Acuerdos (respective years), AHMMR. 
that allowed the nobles to assume debts without running the danger of seeing their patrimonies dissolved. On the other hand, the popular classes had to orient their preferences towards cheap and accessible products. Logically, these changes in demand constituted a challenge to industrial production, which had to become more specialized either in the production of luxury goods or in the most popular items and thus to compete in flexibility with foreign manufacturers.

A great deal has been said about the negative effect of fiscal pressure, which undoubtedly was increasing from the 1560s (Chap. 4 above). However, it is clear that, in macroeconomic terms, such pressure was not excessive, even at the end of the century. Moreover, public spending was also increasing (Yun 1998). But these perspectives do not exempt the state - or, in particular, the fiscal system - from blame for the coming economic difficulties. Taxes in the form of sisas and burdens on the consumption of basic goods (in part a consequence of the conflictive pact) limited the capacity of the artisan workshops to meet costs of maintenance and reproduction, above all because these ateliers depended upon forms of familial economy and apprenticeship. Here it is interesting to underline that, as we have seen, public spending was directed above all towards regions on the periphery-where wars tended to be fought—or resulted in purchases or forced requisitions that were often negative for economic activity. Moreover, the fragmentation of the fiscal map, which was a result of the pact between the oligarchies and the Crown over the matter of resource mobilization, was reaching peak levels. ${ }^{28}$ And this same fiscal system was a background factor in the tendency towards rigidity of the artisan structures (Chap. 5). The sale of common lands accelerated from the 1570 s to 1580 s and had negative effects in the lands of the Meseta-or, at least, in some zones of the Duero Valley.

All of this was concurrently producing a transcendental and progressive change in the credit circuits in a way which has no parallel in other European regions. In the fifteenth century, the accumulation of incomes by the elites had had as a corollary a growing flow of loans towards the countryside and the productive sectors in areas such as the Duero Valley (Bennassar 1983). Now a sizeable share of this tide of money was going in

${ }^{28}$ The purchase of offices dedicated to the regulation of the local market and taxes collected on merchandise by cities and towns contributed to this process. See the case of Salamanca in 1577 in Consejo y Juntas de Hacienda, Libros Registro, leg. 41, sf. AGS. 
the other direction and in particular towards the debts of the state and cities. We know, for example, that a new emission of juros doubled the consolidated debt between 1566 and 1577 and that by 1587 it had reached some 65 million ducats. It is probable that this would grow by almost 50 million ducats between 1566 and 1598, around 1.4 million ducats a year (Ruiz Martín 1975, p. 739). The overall consolidated debt in 1598 had risen, according to the figures (again, somewhat questionable) of F. Ruiz, by 80 million ducats. Another 20 million or more should be added to this figure to account for censos taken out on mayorazgos. This is to say that, without even factoring in the rising levels of municipal borrowing, state debt was above 100 million ducats, a figure superior to the available estimates of Castilian GDP (Cfr, Drelichman and Voth 2014). This is important in itself but is even more decisive if we add that this sum was already far above the size of the monetized part of the economy and, therefore, would exert a notable weight upon the cash flow and the chances of investing in the real economy. ${ }^{29}$

These developments were to have considerable consequences.

The peasant economies were also gradually losing degrees of resource elasticity, a quality that had been crucial to the economic expansion of some regions and strongly conditioned their management (Chaps. 3 and 5). The sale of wastelands (baldios) and communal terrain was progressively reducing the versatility of the peasant economies, a key feature in the previous expansion in certain regions of the Duero Valley (Yun 1987). At the same time, access to wild fruits, wood, firewood, and other primary materials was becoming more difficult, as was the use of pasturelands that allowed the peasants to maintain small flocks (Aranda 1984, p. 143). These sales often ended jointly owned or collaborative agrarian land use arrangements that had been crucial to the previous growth (Yun 2004, p. 466). Many settlements found themselves unable to make use of the opportunities that the 'peasant industries' had previously offered them, manifested in the sale of small numbers of such products or of the goods manufactured from them (Chap. 3).

The sale of jurisdictions was creating uncertainties about the use of waters and soils (Nader 1990) that affected peasant markets and, consequently,

\footnotetext{
${ }^{29}$ On the way these calculations have been produced, see Yun (2004, pp. 464-465). More recently Drelichman and Voth have provided other figures, probably more accurate and based upon the asientos, but they do not change the argument.
} 
the flexibility of family economies. Peasant commercialization of industrial products was rendered more difficult, due to the increasing fiscal pressure on these activities. Another of the conditions that had guaranteed agrarian growth and improvements in work productivity was threatened (Yun 2004, pp. 466-467).

It is possible to imagine in this context that the merchants developing the verlagssystem could take advantage of this situation by involving peasants in industrial activities, thus improving living conditions for the rural masses. But one needs to think that their capital was flowing in another direction and that quite probably the growing jurisdictional fragmentation increased problems by creating more barriers between the urban businessmen and the rural peasants. But the fundamental cause appears to have lain in the above-mentioned changes brought about in the credit circuits and the burgeoning fiscal pressure, as is clearly seen in the case of Córdoba (Fortea 1981).

This was, then, an economy that was progressively less flexible, in which credit circulated in a way that very often was not conducive to productive activities, where the land was subject to management guidelines that were increasingly rigid and where patterns of consumption were changing as the result of two fundamental phenomena: the impact of the crisis that would overcome the country at the end of the century and its capacity to face a series of problems that were met with greater success in other areas of Europe.

\section{The End of Century Crisis in Castile}

This scenario would be affected by a series of precipitating forces that, if not always negative, would severely test the productive system from the 1580s onward.

The wars in the north, the campaign for Portugal, and the problems in Aragon would oblige Castile to make unprecedented efforts that resulted in the increase in public spending to mobilize and provision armies and would have negative effects (Thompson 1992). The sale of jurisdictions and communal lands now reached unprecedented levels. The communities, already heavily indebted, that sought to buy them in competition with nobles and businessmen, found themselves compelled to increase the taxation on consumable goods. ${ }^{30}$ Many of those peasants who were able to

\footnotetext{
${ }^{30}$ Soria (1995, p. 87); Nader (1990, pp.175-179); Pérez and Lemeunier (1984, p. 105); Kagan (1991, pp. 136-138).
} 
assume control of lands had to support debts for many years. The new service of the millones would double the fiscal pressure. And, last but not least, the century's final was marked by a cycle of bad harvests and epidemics of unprecedented severity (Pérez Moreda 1980). Many small farms, and not a few large ones, were affected by similar pressures, as was the urban and industrial system itself. With regard to the former, some had to pay as much as $30 \%$ of their produce. ${ }^{31}$ Factoring in tithes (10\%), and seed costs $(25 \%$ in the case of wheat), these detractions could easily entail $50 \%$ of the net product. ${ }^{32}$ Given the high degree of land occupation achieved in 1580, the violent fluctuation of harvests, and the difficulty in emigrating to unfarmed soils, this tax burden meant that one of the most important pillars for expansion had come to an end (Chap. 3). This situation was made worse by the increase in land costs and their stabilization at the highest level ever reached during the century in the zones of the south, habitually welcoming to immigrants, something which demonstrated the difficulties in continuing the reoccupation of lands at low cost. The imbalance between pastureland and farmland, with a consequent effect in the availability of fertilizer, appears to have gotten worse (Anes 1994), and the increase, until at least 1580, of the price of beasts of burden and transport considerably complicated any prospective response to this problem (Yun 2004 , p. 473 , table 7.3 ). This came in the context of rising fiscal and seigniorial pressures, with difficulties in securing access to other resources and growing rigidities in family economies for the reasons mentioned above. In such difficult circumstances, the loans made available to these peasants in forms of censos, rather than acting as a stimulus to production and the mobilization of factors (as had occurred in the fifteenth century), constituted a form of credit on consumption that was vital for their very survival but could be lethal if, as often happened, they were unable to meet interest payments (Vassberg 1986, pp. 262 and ff.). All of this reduced the margin of subsistence and reproduction of the peasant family and rendered it more vulnerable to poor harvests and epidemics. And it also produced a reduction of both rural work productivity and the range of available resources, thus making it impossible to compensate for falling land yields as had been possible until the third quarter of the century (Chap. 3).

${ }^{31}$ As a result, land rent went up until it reached a century high point in the 1580 s (Yun, 2004, p. 209, Graphs 4.5 and 4.6).

${ }^{32}$ Figures based on López (1990), Brumont (1984), and Vassberg (1986, pp. 224 and ff.). 
If such hardships confronted the small- and medium-sized farms that predominated in the northern part of the Meseta, the situation was also challenging and no more positive for economic growth for the great tenants, who were more important in the southern Meseta and Andalusia. Rent from the cortijos (big farms) and pastureland had grown noticeably but had tended to level off from 1570 to 1580 . Furthermore, a reduction had occurred in the real value of daily wages, and rents paid in coin fell in real terms. But it is no less certain that these farms were negatively affected by the increase in the cost of beasts of burden, which constituted a very important and inelastic part of the exploitation costs (López-Salazar 1986). Moreover, the difficulties involved in the commercialization of certain goods produced by the great farms (such as wool, whose price stabilized and then began to fall from the 1580s) were notable (Yun 2004, p. 74, Graph 7.4; López-Salazar 1987, pp. 30-31). The compulsory purchases for armies increased the insecurity of markets in many areas (Thompson 1976). And this came at a time that the large tenants found themselves facing stiff competition from the great rent collectors, the ecclesiastical and high nobility, when getting their products to the market. This also minimalized the potential positive effects of Madrid on their economies and on the agrarian development in general or had consequences that were so positive at the same time for Paris and London (Ringrose 1983a; Izquierdo 2001; Jacquart 1974).

This is not to say that there were not stimuli in this sense pointing towards the development of a new model of expansion based upon the great farms. As we have said, the very sale of wastelands and communal lands provided the basis for an agrarian capitalism in many areas of Castile and Andalusia in particular, similar to what was taking root in England. But, as we have said (Chap. 5), the result was that in many cases the process encouraged a type of management that was based upon the use of privileges derived from the control of local power or in the double economy of the mayorazgos and did not induce processes of innovation on a large scale. It is not that the big farms were untouched by changes. Considerable innovation was visible in the management of the great olivegrowing estates dedicated to serve the growing demand from America. But, even in this case, this was really a form of farming that was not intensive in terms of local work (rather it depended upon seasonal bursts of a couple of months) and did not encourage immigration from the north to the south as had been the case in the previous phase of expansion. Of the distinct possibilities created by the institutional framework (Chap. 5), the 
less positive ones for economic growth were becoming the most common, and many of the most positive aspects of the sixteenth-century model of agrarian development were running into the sand.

The situation was no better for the urban economies. The problems of provisioning and the high price of foodstuffs posed certain difficulties for the cities. Taking as the point of comparison the relative prices of wheat and canvas, we can see that in the period 1550-1590, the relationship between the former, a basic article for the subsistence of artisans, and an item of merchandise that they sold was increasingly less favourable for them (Yun 2004, p. 464, Graph 7.6). With an agriculture that had reached peak productivity - and, therefore, very high prices of basic productsand with a tax system whose weight fell on foodstuffs, the artisans' margin for manoeuvre was decreasing. Of course, a few factors were in their favour, such as the stabilization of prices of certain primary materials such as wool or the fall of labour pay rates in the case of industry (Yun 2004, pp. 473-474, Charts 7.4 and 7.3). But even then the positive relationship was highly selective, because, in effect, other raw materials, such as cochineal, increased noticeably in price (Yun 2004, p. 428, Graph 7.5).

Tax increases during these years made things even worse. This rise in duties was not greater than in countries such as Holland where, moreover, a large part of taxes were collected as sisas on consumption (Yun 2004, p. 474, Chart 7.4). But, as we will see, Holland had clear advantages in this sense, ${ }^{33}$ and, as we have just seen, sisas levied on the consumption of basic products at a moment of negative terms of trade between agrarian and industrial products could only have negative effects upon artisan workshops.

Clearly, the urban industries were passing through very difficult moments, but-equally evident-different areas had different capacities for reaction to these problems. The textile sector of Segovia was able to resist thanks to its growing specialization in high-quality woollen cloth (they were even exported to America) and to the use of a salaried labour force in some phases of production, which would permit it to externalize the maintenance costs of the workforce (García Sanz 1987). Toledo did

\footnotetext{
${ }^{33}$ It is fairly probable that an unqualified construction worker in Valladolid would have dedicated around $30 \%$ of his annual income to pay taxes, while his Dutch equivalent would have hardly had to contribute more than 20\% (Yun 1999c; De Vries and Van der Woude 1997, p. 97).
} 
the same, producing high-quality goods (silk fabrics) to meet elite demand (Montemayor 1996). But the problems were very considerable in cities such as Córdoba, subject to important rigidities and to local negotiations about taxes that did not always favour the artisans or their ability to adapt to new patterns of consumption (Fortea 1981).

The rigidity of the commercial circuits was also to have very negative effects at the end of the century. The problem would also become manifest in the wheat market. The imbalance between supply and demand would get worse when, on each bad harvest, the cities proceeded to prohibit 'exports' or to seize the cereal passing through their jurisdictions. The practice of compulsory purchases and seizures at the price of cost (Thompson 1976), understandable and necessary, further increased the rigidity of the market and, as usual in these cases, had repercussions in the price of industrial products (Yun 1980). Far from fomenting a system of multilateral interchange, the outcomes were a greater opacity and a number of new risks that delayed the adjustment between supply and demand.

In a large and mountainous country, with highly populated cities in the interior, effective and flexible networks of distribution that could adapt to all circumstances were necessary. But this need did not necessarily ensure their existence. The situation has been described by A. Sen in relation to hunger in the contemporary Third World: there existed a problem of supply and a concentration of demand in the cities; in addition, there existed problems of distribution that were related to the institutional framework and the network of local interests in this society (Sen 1981). In this context the transfer of the court to Madrid was a significant event. The positive effects of this move should not be forgotten. The capital was established far from the fertile soils of the Duero Valley, and in the heartlands of southern Meseta, still highly expansive in terms of its agrarian resources. From 1560 to 1600, the population of Madrid passed from 12,000 to almost 90,000 inhabitants (Carbajo 1987, pp. 132-138). Its positive impact upon the market and the surrounding areas was quickly felt. Madrid's demand contributed to maintaining New Castile's expansive wave of agriculture until the last decade of the century. Many nobles with possessions in zones near Madrid began to invest in agriculture. Cities such as Toledo or Segovia found a vibrant market for their products (Montemayor 1996). But Madrid was a strange addition to the established urban networks. Rather than grow and simultaneously provoke the reconfiguration of the urban system, Madrid attracted artisans and population from its surroundings, creating a vacuum in these satellites (Ringrose 1983a). The urban network of the Meseta would now enter into 
a process of crisis, which would last throughout the first decades of the seventeenth century (Chap. 8).

In these ways the impulses towards agrarian and urban growth of the sixteenth century were rapidly diminishing. Many of these problems also existed in other regions. But it was the centre of Castile, the region that had been an epicentre of economic growth, which was suffering the most from the negative impact of the institutions and management criteria created by the conflictive pact among the elites. The relative delay that would overcome the economies of the centre of the peninsula can, however, only be understood in relation to the comparative advantages of other areas of Europe.

\section{The Advantages of the Enemies}

The degree of flexibility of the different economies and their capacity to take advantage of international relationships were crucial. Both factors were tied to the institutional frameworks and political economies that resulted from the way the different regions faced the century's structural tensions.

In the 1590s the receipts of American treasure peaked at 11 million ducats a year, a figure which would not be surpassed for decades to come. At the same moment that the Spanish expenditure and the transfer of silver to the rest of Europe were increasing, the peace treaties of the early seventeenth century and the accumulative effect of the improvements in commercial and financial organizations favoured a greater fluidity in international commerce. The results would be a further move towards the integration of international trade and, with it, a higher degree of competition between the various regions: these conditions brought about an unprecedented fight for markets. In these circumstances the capacity for reaction depended upon the flexibility of economies, which in turn was conditioned by their political and institutional systems.

France's economic situation by 1600-1620 was much healthier in general terms than that in most parts of Spain, particularly its interior, and Portugal. France, and its Atlantic coastal regions above all, enjoyed more benign ecological conditions, with Atlantic climates bringing greater humidity. It also enjoyed proportionally larger woodlands in many parts of the country, thus permitting a triennial rotation of crop cultivation. For these reasons the agriculture of the north was more easily able to overcome the productive blockades without having to employ revolutionary new technologies (Jacquart 1975, pp. 216-226). 
But this was not France's only advantage. As we have seen, the aristocracy's need for economic innovation was higher in France than in Castile. This was not only evident in the management of aristocratic estates like that of La Trémoille but also in the development of agronomic theories to an extent unknown in countries such as Spain (Weary 1977). Ecclesiastic properties were less extensive in France than in Spain, especially after the alienations of the previous century. The reduction of the taille following Sully's reforms also allowed the peasants - and, in particular, the owners of small farms-much more room to manoeuvre (Jacquart 1975, pp. 213-215; and Holt 1995, p. 212). In complete contrast to the situation in Castile, cities in France still enjoyed a more fluid relationship with the countryside. The French urban network, centred around Paris and gravitating towards the great arteries of international trade in the north, would encounter problems in the course of the seventeenth century. These difficulties, however, were relatively minor in comparison with the complete collapse and dramatic shift towards macrocephalia of the urban systems that occurred in the interior of the Castilian plain. Taking into account the vicissitudes of the various centres, the structure, spatial division, and density of the French network became stronger, with some scholars even speaking of a period of growing urbanization (Benedict 1989, pp. 27-39). Even with the changes brought about by the lowering of the taille, the fiscal burden appears to have fallen more equitably between city and countryside; at the same time, the paulette favoured the better-off social groups but only to a relatively small degree (Bonney 1981, pp. 61-62). The close links between the cities and the great trade routes, the development of the verlagssystem, and the strong impetus given to the luxury goods industries by the demands of the international market, including that of Spain and more and more that of America, may help to explain the cities' dynamism and vitality, which was also a stimulus for the resistance of the rural areas.

The results were a more flexible economy, a more even distribution of incomes, and higher levels of productivity in France than in most areas of Spain. This was especially clear in the areas of the north-those above a line drawn from La Rochelle to Strasbourg. Here positive conditions were engineered, with both urban industry and rural production fed by Parisian demand. Here also the war with Spain and the integration of the area into international trade circuits had some positive effects on the textile production of Brittany, Nantes, and other zones. Papers, books, and other products were also positively affected (Lapeyre 1955, pp. 507-596). 
The development of lines of commerce between the north and the south of Europe, the incremental advance of Atlantic trade, and the high levels of agricultural productivity contributed to generate a relatively flexible and competitive economy in this area.

In England the model of development that had emerged during Elizabeth's reign was gaining strength and momentum. The impetus afforded by the markets exerted its impact upon an economy which, in clear contrast to the Spanish model, appears to have been exceptionally receptive and flexible. One manifestation of this change was the growth of London in parallel to other urban centres. As we have seen, the much narrower political incomes of the aristocracy and the need to overcome their debts compelled them to diversify and increase their investments. These were channelled not only into agriculture but also, increasingly, into mining and commerce-a development without parallel in the other two countries (Stone 1979, pp. 335-384). England was progressing towards an open society in which entrance into the highest aristocratic circles was accessible to the gentry and even to businessmen (Stone and Stone 1995).

An old interpretation, advanced by Kerridge, is nowadays questioned: this held that the years 1560-1640 had witnessed the strengthening of agrarian capitalism and a period of great innovation on the large English estates. Later research has placed emphasis upon a 'first agrarian revolution', led by a vanguard of yeomen and whose bases would be the mediumsized farm, the intensification of work patterns, and connection forged with expanding local markets (Allen 1992, p. 310). These farms oversaw the 'prolonged transition from mainstream agriculture to alternative agriculture', characterized by the introduction of livestock fodder crops (among them clover and turnips) and made possible by a considerable degree of flexibility in the patterns of crop rotation (Thirsk 1997, pp. 24-25). Whatever the origins of the English agrarian transformations, they cannot be understood without taking into account the relatively high degree of mobility in the land market in comparison with Castile, thanks to a system, the strict settlements, which were less rigid than that of the mayorazgos (Habakkuk 1994). In complete contrast to what was occurring in Castile, this development allowed the redistribution of land towards the more dynamic and innovative sectors of the economy.

These shifts ran parallel to the greater orientation of the peasant economies towards industrial activities, which saw the emergence of the 'new draperies', in part thanks to commercial expansion towards the south of Europe. This development can be seen as the prelude to an industrious 
revolution', to use the terminology of Jan De Vries (2008). The fact that an important part of industrial activity was in the hands of peasants not only reduced costs but also avoided the emergence of very large cities (London being the exception), with all the provisioning problems that this entailed for cities such as those of Southern Europe. English changes were also in part made possible by merchants' willingness to invest in rural industries that were the bases for textile exports (Wrightson 1982, pp. 143-144). With a smaller tax system, the public debt was also more limited than in Castile - and, therefore, its capacity to attract private savings was also reduced.

This expansive model possibly led to a more even distribution of incomes than in Castile and, by extension, greater opportunities for the industrial goods market. It also offered greater resilience to increased fiscal demands. The growing demands of the parliamentary subsidies notwithstanding (by 1600 these revenues were worth more than those coming from the Crown lands and customs charges), fiscal burdens were easily met by a more flexible economy in which peasant multi-activity increased per capita wealth at the same time as it regularized income and the monetary flow coming from abroad facilitated tax payments. Far from thwarting productive activities, the growth of land rents and demographic pressure in fact led to an increase in auxiliary peasant activities (transport, peddling, domestic industry, etc.) as a means of overcoming these rising extractions. Even if this model reached a glass ceiling in the 1630s, still the cycle of expansion begun in the previous century had been a long one and may even have witnessed the most rapid phase of English economic growth in the early modern period (Snooks 1994; Allen 1992). There is no doubt that English goods were very competitive on the international market.

The evolution of the United Provinces followed a path similar to that of England. As in Castile, the fragmentation of the internal market was remarkable due to the uneven fiscal policies implemented by the different provinces. As has been said, both countries had similar tax systems, with heavy excises levied on basic goods. As in Castile, Dutch industrial production was mainly based on urban workshops under the control of guild regulation. The very high degree of urbanization and demographic pressure also provoked food supply problems, particularly for wheat, in both areas.

But the economy of the United Provinces was better prepared for these challenges. Its central role in international commerce-and particularly in the Baltic cereal trade-mitigated provisioning problems. For the reasons explained before, until at least 1650 , the Dutch nobility displayed 
a widespread inclination towards investing in agrarian improvements (Van Nierop 1984, p. 138) and were, therefore, more immune than their Castilian peers to the attractions of rent-seeking and rentier practices until very late in the seventeenth century (Burke 1974, pp. 132, 139). Urban patricians who had made their fortunes in commerce tended to see high prices and increasing demand as a good reason to invest in the draining of relatively extensive areas and the introduction of productive improvements (De Vries and Van der Woude 1997, pp. 28-29). This contrasted with the avidity for land for purely rentier purposes that was so common in other parts of Europe, such as Castile. Furthermore, regional variation notwithstanding, it was the small and medium farms that were crucial in this regard, and the improvements in land productivity helped to smooth the negative effects of the increasing rents paid by peasants at the same time that growing economic multi-functionality and diversification widened sources of income and available resources. ${ }^{34}$ The development of fishing and the attendant pickling or salting industry rounded off the incomes of the Dutch people (De Vries and Van der Woode 1997). The arrival of immigrant artisans from the southern Low Countries in the Hamburg region (Israel 1989, pp. 30-37) and subsequently in Holland provided the country with the main economic factor crucial to the industry of the time-human capital. This allowed for the production of high-value-added goods and, consequently, enhanced the taxpaying capacity of industry.

An economy of this sort-oriented to international demand, characterized by enhanced productivity and high-value-added activities-was able to withstand increasing fiscal pressure on family consumption. But this was not its only strength. The solidity, high commercial awareness, and relative wealth of the middle classes - both craftsmen and bourgeois - made possible the mass issuing of renten, public debt bonds, which facilitated the development of Europe's first financial revolution ('T Hart, Jonkers and Van Zanden 1997, p. 22). Very shortly, these conditions allowed the great commercial companies, the VOC and WIC, to sell off huge numbers of their shares. In turn these companies came to monopolize trade with the West Indies, the Mediterranean, and East Indies (Israel 1989).

\footnotetext{
${ }^{34}$ De Vries and Van der Woude (1997). A definition of these two terms can be found in Durand and Van Huylenbroeck (2003).
} 
These practices led to the foundation of powerful commercial institutions supported by private capital and a multitude of small investors. A development of this sort, unthinkable in Castile despite occasional efforts in this direction, meant the creation of organisms whose prosperity was of direct interest and concern to large parts of the population and which, in addition to being directly involved in commercial development, would henceforth serve as the basis for the extension of Dutch trade across the face of the world (Israel 1989). Progress in sailing techniques would shortly culminate in the birth of a new type of ship, the fluyt, whose emergence was primarily possible thanks to the availability of capital, although mention might also be made of a variety of other factors, among them cheap wood from the Baltic (De Vries and Van der Woude 1997, p. 357). In 1621 the war with Spain again broke out. By this time Holland boasted one of the most versatile, solid, and competitive economies in Europe.

If less dynamic, the economy of the Spanish Netherlands was not entirely different, although historians have often dismissed it due to the unfavourable comparison with the prodigious Dutch advance. War did, of course, provoke enormous disruption, but the recovery was perceptible (Van der Wee 1994). As in Holland, the economy was based upon intensive farming, with crop rotation (specifically exploiting tuberous plants) increasingly significant in some areas. Reclaimed land, such as the former marshes between Dunkirk and Furnes, attracted capital investment from the nobility and businessmen as well as the efforts of a multitude of small family farmers. Another similarity lay in the flexibility of agriculture, which was innovative and less burdened by seigniorial restrictions than was the case in Southern Europe. Industrial activity was not confined to the cities but was also common to rural areas.

If the great Atlantic-Baltic trade routes increasingly passed around the southern Low Countries, then its political links with Spain allowed it to develop a flourishing trade with Seville and Madrid (Van Houtte and Stols 1973). The consequent external demand, in conjunction with the domestic markets, fed industrial production. After 1560 improvements in levels of industrial production were only marginal, but the demand for luxury goods elicited a quick response in many of the urban industries such as silk textiles, tapestries, jewellery, art, and so on. This demand coincided with the survival of the industries where the verlagssystem predominated and that provided popular manufactures (knitted or woollen fabrics) (Van der Wee 1988, pp. 347-351). The transfer of Spanish silver, which remained stable after reaching a peak in 1605 (Gelabert 1997, 
pp. 49-54), continued to give impetus and energy to the regional economy and the circulation of money, a crucial consideration for a dynamic and commercialized economy such as this one.

In Italy, even after the peace signed with Holland, Spanish demand fed the production of textiles, weapons, tapestries, and other expensive products originating in the north of the country and consumed in the Italian and Spanish courts. The flow of silver and spending provoked by war had a positive side also here. The war and the strengthening of these trade circuits provided impetus to cereal production in the South, a programme the Sicilian nobles enthusiastically sponsored as a means of escaping from their crippling debt problems (Cancila 2013). Even those Italian scholars who argue that the model for growth was broken in the last decades of the sixteenth century emphasize the ability to overcome the crisis and the resilience of trade networks. Florence made full use of Spanish wool and demand for luxury textiles, both of which were crucial to the restructuring of its industry towards the production of silk fabrics after 1575 (Ruiz 1990a, pp. 110-147; Malanima 1978, p. 237). In Milan this same sector, with others linked to it, continued to advance with considerable momentum, as did the Venetian woollen cloth industry.

Yet the indicators Ruggiero Romano used to measure Italian vitality until 1619-1620, like other sources explored more recently by scholars, offer clear evidence of problems. These studies do not, of course, reveal a recession of uniform depth and characteristics across the entire peninsula. ${ }^{35}$ But, by 1620, the rigidity of the Italian economy was clearly greater than those of its northern rivals.

One of the problems was of a Malthusian character, manifest in the famines and high grain prices of the 1590s and resulting in a lowering of the demand for industrial goods. Skilled workers were being squeezed by rising costs of living. The result, as one Elizabethan traveller would note, was that grain was now more costly than in England-34\% more expensive, according to Vigo (1998, p. 280). But this was not the only obstacle.

At the heart of everything stood the problem of market integration and economic structures. The extreme political fragmentation of the Italian Peninsula had meant that the numerous local economies had never properly integrated - a fact reflected in the concave distribution of the

\footnotetext{
${ }^{35}$ The high point of woollen cloth production was reached in 1591-1600; after this point the tailing off was unchecked. The fall of the 'tassa sull'ancoragio' is also evident from 1603 to 1605 (Romano 1962, pp. 492 and 501); the same can be said about urban production of silk fabrics (Ciriacono 1988, pp. 46-47; Vigo 1998).
} 
urban network, which had not changed in this respect (De Vries 1984), and which raised the cost of the transport of wheat. In moments of dearth, the zones with a surplus found it difficult to provision the industrial areas of the north. Political disunity also posed an obstacle to the movement of primary materials for industry. An area with such an advanced technical division of labour, and with an industrial population that was clearly dissociated from food production, easily passed these additional costs onto prices (Vigo 1998, p. 280).

Another problem lay in the lack of flexibility and scope for innovation among the artisan sector, which reduced the degree of integration between city and rural areas. ${ }^{36}$ Florence provides a good example. Throughout the seventeenth century, rural and urban industrial sectors remained separate (Malanima 1988). P. Malanima has stressed that the high opportunity costs and inherent risks were obstacles to change in mature economies such as these (Malanima 1998). Similar arguments gain strength if we factor in the existence in Italy of alternative investment strategies which, from the end of the sixteenth century, had attracted capital to purchase land (but not always to gain higher levels of productivity), fiefs, political offices, and so on. All of these considerations underline the fact that investors harboured profound doubts about the direction of imperial policy, which was very unlikely to be formulated for their benefit.

This structural rigidity appears to have had other consequences. The model of an 'Italian' agriculture unable or unwilling to change has been abandoned, at least in relation to the north of the peninsula. In Lombardy and even in Tuscany, efforts were made to improve fields and to extend the mulberry tree throughout the seventeenth century; these labours were sponsored by the great landowners who invested in them their fortunes, which had generally been obtained in commerce. Yet this trend could also lead to serious blockages, such as the one that overcame the Tuscan textile industry. Here the development of the verlagssystem, with a rural cycle, was obstructed by new farming techniques depending upon high-intensity labour throughout the year, thus reducing the time that peasants could devote to domestic industrial activities (Malanima 1988).

The eye-catching development of the financial and fiscal systems of the Italian city-states and kingdoms also had a negative effect. In the citystates of the north, as in the kingdoms of the south, these schemes resulted in a growth of public debt. In turn bankers and merchants came to see the option of loaning monies to governments as 'much more attractive than

\footnotetext{
${ }^{36} \mathrm{P}$. Malanima sees the lack of flexibility in the Italian industrial economy as a result of its excessive 'maturity' (1998).
} 
investing in industry'. ${ }^{37}$ These were, moreover, political systems that generated highly evolved patronage structures, offering numerous offices and incomes to elites, thus further reducing the attraction of risky investments in industry. Another attractive investment for the great noble and banking families was the purchase of works of art, buildings, and palaces or in financing diplomatic or military careers.

Clearly, improvement was possible in Italy or Southern Europe in general. But, when set in comparative terms, the disadvantages of this system in comparison to the changes taking place in Northern Europe were obvious. Set against Dutch arrangements (its chief competitor), the Italian 'crisis' of the first decades of the seventeenth century was one of relative recession and readjustment. The maps representing the European urban networks in 1600 and 1650 (Maps 6.1 and 6.2) as well as the map representing the European urban trends (Map 8.3) are very meaningful regarding the extent to which the shift of economic development towards Southern England and the Low Countries was taking place.

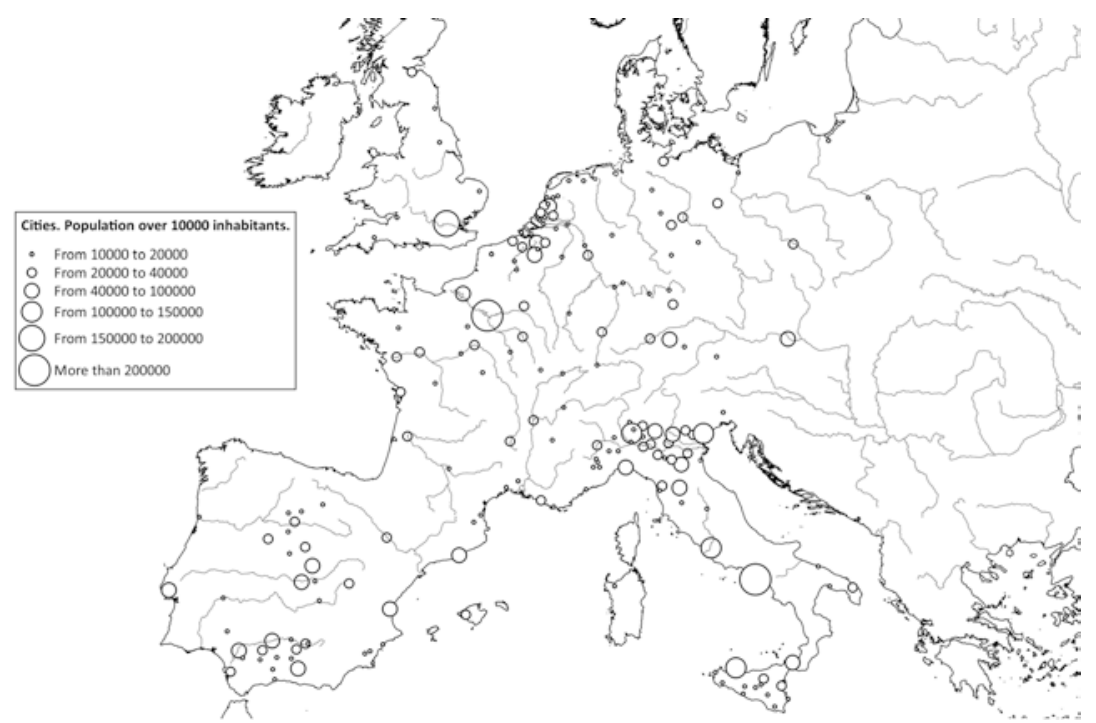

Map 6.1 European urban networks, 1600

Sources: My own elaboration with data from De Vries (1984) and my data of Spanish towns.

${ }^{37}$ The phrase comes from Davidson (1985, pp. 163-164) and refers to Venice. See also the case of Naples (Calabria 1991, pp. 104-147). 


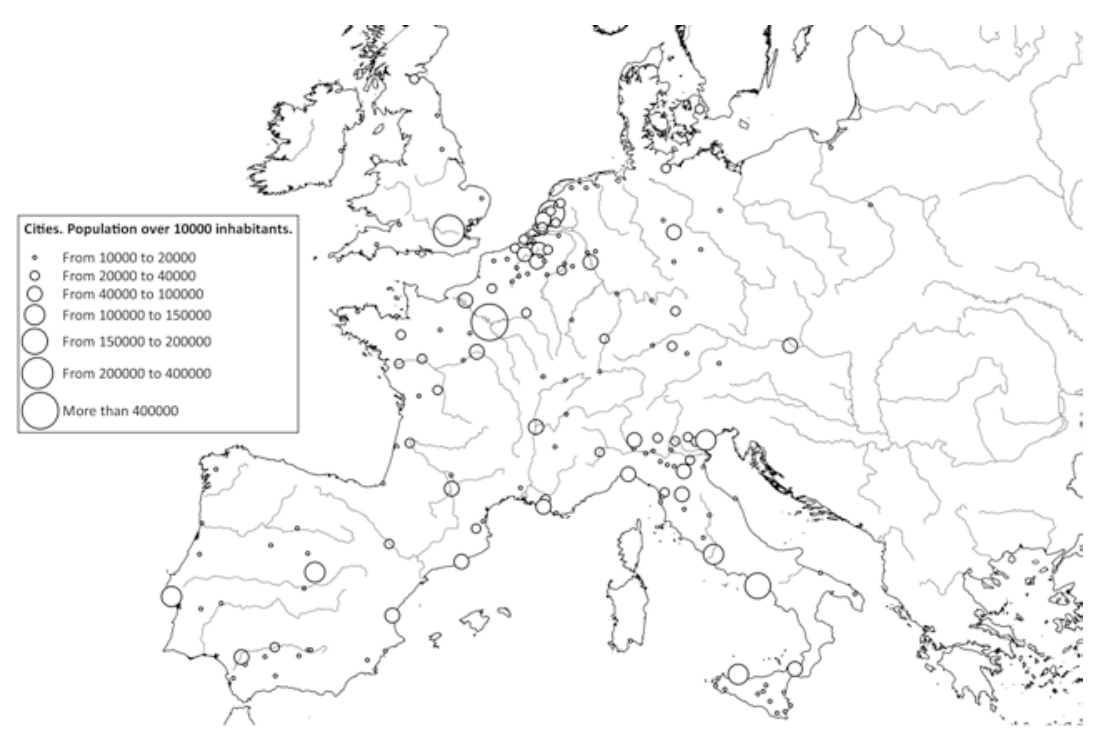

Map 6.2 European urban networks, 1650

Sources: My own elaboration with data from De Vries (1984) and my data of Spanish towns.

By 1600 European globalization had escaped the hands of governments. In truth, they had never controlled it. But by this point, a series of informal networks were beyond their reach. It is often remarked that the king in Madrid was unable to exercise his monopoly in the Indies, as well as in Africa and, even more, in Asia, to control emigration to them or the merchandise that was sent to-or received from-them. This failure was, however, nothing more than a reflection of how empires were-and are-unable to control the circulation of merchandise, goods, ideas, and persons. Understanding this incapacity is vital for what will follow.

At the same time and in spite of the small numbers that globalization meant in commercial terms, it was having profound effects on the life of Europeans. As we have seen in Chap. 4, its first steps had been crucial for the reproduction of the social order and institutional framework on the Iberian Peninsula. But the formation of global connections would be also decisive for many other areas of Europe: it enhanced the integration of international markets within Europe, thus increasing economic and political competition among European polities. 
Here, we have tried to argue that, among other factors which fall outside of our study, the capacity of the different countries to overcome tensions and, above all, of the dominant coalitions to reproduce themselves was indirectly tied to their position with respect to globalization and imperial connections. By analysing how the different challenges that those societies faced were addressed, one can better understand the role of their empires in Iberian societies and more in particular in Castile and Portugal.

The availability of silver and imperial resources in Castile and Portugal, which were also part of the globalizing process, was an important factor for the evolution of many Western European regions. And these factors, combining with internal ones, in which religion and religious confrontation were not negligible, were behind the breakdown (or survival and deep recomposition) of the different areas' dominant coalitions. Those factors were also behind essential changes-often forgotten in the study of European political economies - that affected the degree of efficiency in the use of resources in relation to economic growth. It should be emphasized - and should be clear from the previous pages - that the term political economy cannot be reduced to the simple working of formal institutions. Essential aspects - such as the creation of confidence-did not depend only upon such institutions: nor, in the short term, did growth and crisis. A range of aspects such as the position of each country in the transnational networks that distributed these resources, the different endowments of factors, and the way in which they were organized in agro-urban ecosystems were important and would continue to be so in the seventeenth century.

Open Access This chapter is licensed under the terms of the Creative Commons Attribution 4.0 International License (http://creativecommons.org/licenses/ by $/ 4.0 /$ ), which permits use, sharing, adaptation, distribution and reproduction in any medium or format, as long as you give appropriate credit to the original author(s) and the source, provide a link to the Creative Commons licence and indicate if changes were made.

The images or other third party material in this chapter are included in the chapter's Creative Commons licence, unless indicated otherwise in a credit line to the material. If material is not included in the chapter's Creative Commons licence and your intended use is not permitted by statutory regulation or exceeds the permitted use, you will need to obtain permission directly from the copyright holder.

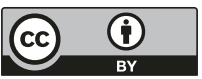

